\title{
Simona Gurbo
}

\section{POLITICS AND RELIGION: POLITICAL BEHAVIOUR OF CLERGY IN LATVIA (2002-2012)}

Abstract of doctoral dissertation for acquisition of the scientific degree in political science Speciality -51310 


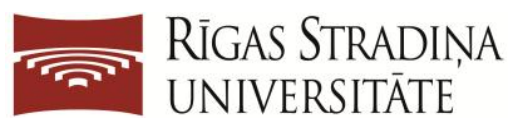

Simona Gurbo

\section{POLITICS AND RELIGION: \\ POLITICAL BEHAVIOUR OF CLERGY \\ IN LATVIA (2002-2012)}

Abstract of doctoral dissertation

for acquisition of the scientific degree in political science

Speciality -51310

Rīga, 2013 
Promotion work has been worked out at: Rīga Stradinš̌ University

Scientific supervisor:

Professor Ilga Kreituse, PhD, Rīga Stradinš University

Official reviewers:

Assistant Professor Ivars Ījabs, PhD, University of Latvia

Professor Jel̦ena Staburova, PhD, Rīga Stradinš̌ University

Professor Valdis Tēraudkalns, PhD, University of Latvia

Defence of the promotion work will take place on the 20th of December, 2013 at 10.00 in the open meeting of Political Science Promotion Council of Rīga Stradinš̌ University in Rīga, 16 Dzirciema Street, Lecture Theatre Hippocrates.

Promotion work is available at the RSU library and RSU home page: www.rsu.lv

Secretary of Promotion Council:

Dr. hist., Professor Jel̦ena Staburova 


\section{CONTENTS}

Introduction ...........................................................................................................

1. Theoretical Framework of Politics and Religion: Institutional and Socio-political Context .............................................................................10

1.1. Institutional Framework of Politics and Religion: Church and

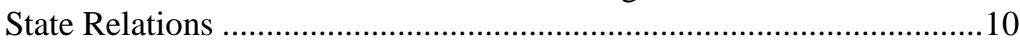

1.2. Theoretical Aspects of Political Behaviour of Clergy ………………....13

2. Church and State Relation Development in Latvia ....................................20

2.1. Historical and Institutional Relations of Church and State in Latvia ....20

2.2. Political Activities of Clergy in Latvia .................................................23

3. Political Behaviour of Clergy in Latvia ......................................................30

3.1. General Characterisation of the Socio-political Behaviour of Clergy: 2002-2012 …………………………………………..... 30

3.2. Political Behaviour of Clergy in Latvia: Empirical Study ......................33

3.2.1.Conceptual and Methodological Justification of the Empirical

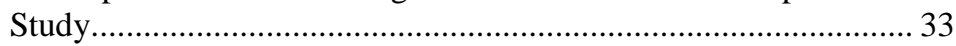

3.2.2. Results and Analysis of the Empirical Study ............................... 39

Conclusions................................................................................................................53

Bibliography ..........................................................................................................59 


\section{INTRODUCTION}

World War II changed not only the world's political map, but it also affected research methods in social sciences. The increasing popularity of behaviouralism in political science allowed researchers to pay more attention to the political behaviour of individuals and groups, rather than the analysis of power and political institutions. This approach greatly influenced research on political behaviour and the role of religion in politics.

Most studies initially analysed the impact of religious beliefs on policy-making, as well as the importance of individual denominations on electoral behaviour (Berelson, Lazarsfeld, McPhee 1954, Gilbert 1993). Other researchers focused on issues that explained, e.g., the impact of religious institutions on civic skills, social skills and networking (Verba, Schlozman, Brady, 1995). Many studies that were carried out in the United States and concentrated on the research of religious institutions and civil society and political participation (Milbrath \& Goel 1977; Hougland \& Christenson 1983; Martinson \& Wilkening 1987, Peterson 1992, Harris 1994, Verba, Schlozman, Brady in 1995, Macaluso \& Wanat 1997) showed that churches can promote political participation levels of their members, developing and teaching necessary civic skills. This aspect in political science was known since the beginning of studies on political culture and political participation, since churches just as other socialisation agents have always been known to contribute to peoples' beliefs, values and political skills.

The role of clergy in American politics has been studied for a long time even though initially in the 50s and 60 s these studies concentrated on leading mass communication theories. They analysed clergy as opinion leaders and their impact on parishioners. ${ }^{1}$ Since the content of the communication flow was oftentimes obscure to broader masses, clergy as opinion leaders interpreted

\footnotetext{
${ }^{1}$ Corwin Smidt, "Clergy in American Politics: An Introduction," Journal for the Scientific Study of Religion Issue 42, Vol. 4 (2003):495
} 
the information according to their views, making it clearer to many people. This, as many researchers assumed, increased their political participation, civic activity and civic efficiency. The second wave of political and religious studies began in the 70s, when researchers such as Jeffrey Hadden, James Wood and Harold Quinley (Hadden 1969, Wood 1970 Quinley 1974) started their research on clergy and lay persons in politics, their attitudes towards political processes and their political behaviour.

As a result, in the recent years a wide array of research has accumulated regarding the importance of clergy as opinion leaders, community activists and even campaign managers (Guth et al. 1997). However, there have been few studies that have attempted to explain the reason why some clergy are politically active, whereas others are not. Researchers have quite often used qualitative studies (case studies), rarely using quantitative research. As a result, the theory of political behaviour of clergy is still in its development stage, and there are many unanswered questions.

So far, few studies have been carried out in Latvia that would study the political and religious context, which often manifests itself in Church and State relations, whereas clergy and their political behaviour have not been studied at all. Additionally, it should be noted that there are relatively few studies on the political behaviour of Catholic clergy and virtually no studies on the political behaviour of Orthodox clergy. The same applies to Old Believers. The absence of research on the Orthodox and Old Believer clergy can be explained first of all by the complex and sometimes obscure relations these churches have with the secular powers, and second, the closed nature of the Churches themselves, which is reluctant to disclose insider information.

In a practical sense the topicality of this theme is determined by The Latvian First Party (hereinafter LPP), which was founded in 2002 and set the implementation of Christian values in the society as its primary goal. LPP members (e.g., Ēriks Jēkabsons, Ainars Baštiks, Jānis Šmit, Juris Lujāns) 
started an active and initially positively valued campaign in Latvian churches. Throughout their cooperation with many clergy members they tried to gain support from Christian voters, and partially succeeded at it. This raised the question of how important clergy members are as opinion leaders, since the invitation to vote for parties, which are based on Christian values, could be heard quite often in churches. In the following 10 years the political activities and alliances of LPP acquired a negative evaluation among many clergy members, and their support decreased. Precisely for this reason the time frame of the empirical study has been set from 2002 until 2012, even though chapter 2 will give the historical background for the political activities of clergy.

Religion is a broad concept, which even when narrowed down to one religion - Christianity leaves us with many denominations fragmented by their theological, institutional and organisational beliefs. There is no state church in Latvia and the laws lack a legal definition of the term 'traditional religion' or 'traditional denominations'. At the same time, Article 51 of the Civil Law of the Republic of Latvia states that clergy of the following denominations have legal rights to issue marriage certificates - Lutherans, Roman Catholics, Orthodox, Methodists, Baptists, Seventh-day Adventists, Old-believers and Judaists. Hence, the seven Christian denominations are considered 'traditional denominations' in Latvia.

This thesis will analyse only the clergy of traditional Christian denominations, therefore, the research field includes the clergy of the Evangelical Lutheran Church of Latvia (hereinafter - ELCL), the Roman Catholic Church in Latvia (hereinafter - RCCL or the Catholic Church), the Latvian Orthodox Church (hereinafter - LOC), the Pomorian Old Believer Church in Latvia (hereinafter - POBCL), the Union of Baptist Congregations in Latvia (hereinafter - UBCL), the Union of Seventh-day Adventist Congregations in Latvia (hereinafter - USDALC or SDA) and the United Methodist Church in Latvia (hereinafter - UMCL). According to data published 
in 2012 by the Ministry of Justice, in 2011 there were 750 clergymen in Latvia, and 636 clergy members served in the denominations listed above, breaking down as follows: Lutherans - 209, Catholics - 166, Baptists - 97, Orthodox 88, Old Believers - 36, Adventists - 29, and Methodists - 11 .

The object of this research is 'clergy'. Even though there are no significant differences in the understanding of clergy in Latvia, it would be impossible to study the political behaviour of the entire body of clergy in Latvia, therefore monastic clergy, deacons and retired clergy, or emeritus will be excluded from the study.

The subject of this research is 'political behaviour', including political participation and political activity. Particular attention will be paid to the political activities of clergy, including running for office, participating in political campaigns, encouraging people to political participation, praying for certain politicians, talking in sermons about political or social problems, or asking people to vote for a certain political party or candidate.

The aim of this research is to analyse and compare the political behaviour of traditional denominational clergy in Latvia and identify its causes. Thus the following tasks are set:

- Analyse the theoretical literature on politics and religion in terms of Church and State relations.

- Give an insight on Church and State relations since the foundation of Latvia.

- Describe the trends of political behaviour of clergy in Latvia.

- Carry out research using quantitative research methods, questioning respondents with closed and open type questions on the political behaviour and socio-political activity of clergy in Latvia.

- Give a characterisation of the political behaviour of clergy, based on the results of the study and provide an interdenominational comparison of the political behaviour models of clergy in Latvia. 
The following hypotheses are given:

H1 Socio-political activities of protestant and evangelical clergy are higher than those of Catholic, Orthodox and Old Believer clergy, which is affected by the freedom of ritual in their churches.

H2 The political behaviour of clergy is primarily determined by their denomination, rather than their age, or location of the Church.

H3 The political behaviour of clergy is stimulated by their personal theological views on social issues - affective and evaluative beliefs on Church and State relations.

H4 The political behaviour of clergy is encouraged from the outside, i.e., political party members desire to decrease the alienation that is taking place in the society, and the Churches in return desire to spread the Christian message and promote spiritual values in the secular society.

In order to achieve the aim of the research, fulfil the tasks and test the hypothesis, theories of clergy political behaviour will be used (Ted Jelen, James Guth). To describe Church and State relations I will use Frans Hoppenbrouwers' work on Church and State relations in the Baltic States since the collapse of communism.

Research methods: In order to research the political behaviour and socio-political activity of clergy, I will use quantitative research methods. In order to study the political behaviour of clergy in Latvian congregations, I will carry out a quantitative study - a structured questionnaire with closed and open questions. The data for the quantitative study will be acquired by interviewing the target population as part of a non-random (non-probability) sample. The questionnaire will primarily allow to provide answers to three dominant groups of questions: (1) what is the political behaviour of clergy and what is their own assessment of their socio-political activity, (2) what are the theological beliefs of clergy (conservative-liberal), (3) what are the mobilization possibilities of 
clergy (age, church size, church location). The acquired data will be processed using IBM SPSS Statistics, Version 20.0. Additionally, I will use structured interviews with experts - several members of the clergy, in an attempt to clarify a number of aspects of their political behaviour.

The first chapter will focus on the political and religious context of Church and State relations in the 21st century in their institutional and sociopolitical framework. This chapter will also give the theoretical background of political behaviour of clergy and explain their impact on socio-political processes.

The second chapter will reveal the issues of Church and State relations in Latvia, giving a brief reference to the institutional relations of Church and State in Latvia, but also giving a summary of historic clergy behaviour and their political activities since the foundation of the Latvian state. The historic background is important, because it can provide us with an understanding for the reasons behind clergy political behaviour.

The third chapter will analyse the political behaviour of clergy in Latvia. Based on data and results acquired as part of the empirical research, I will analyse and compare the patterns of political behaviour of clergy and analyse questions, which arise from the hypotheses listed above. 


\section{THEORETICAL FRAMEWORK OF POLITICS AND RELIGION: INSTITUTIONAL AND SOCIO-POLITICAL CONTEXT}

\subsection{Institutional Framework of Politics and Religion: Church and State Relations}

Politics and religion in their institutional framework most usually may be identified in Church and State relations; therefore the following chapter will give a short insight into Church and State relations.

In today's age of globalisation the influence of churches on sociopolitical processes are subject to rapid changes, especially in view of global modernism and secularism. Secularisation is particularly important to this study, because it can at least partially be considered the cause for the political activity of clergy - as secularisation affects the society, and churches become increasingly marginalised from the political, and sometimes even from the social sphere, the clergy try to maintain their social impact (sometimes also political) through various activities.

Empirical evidence of secularisation trends around the world show that in comparison to the US, Europe may definitely be considered a secularised region, because religious activities tend to decrease. Many believe that religious activity is high in countries where "economic stagnation and political instability" ${ }^{2}$ take place, however that does not explain the religious activity of the US, which currently has some of the highest religious participation levels in democratic countries, standing at 53 per cent (believing religion to be a very important part of their life); in comparison to 16 per cent in the UK, 14 per cent in France and 13 per cent in Germany.

Considering the fact that the society in Latvia is notably secular, as specified by the European Value Survey, it is interesting to note that churches have the highest trust levels in the society. Data show that in $1990-64$ per cent

\footnotetext{
${ }^{2}$ B. A. Robinson, "How Many People Go Regularly To Weekly Religious Services?" November, 2001. Ontario Consultants on Religious Tolerance, www.religioustolerance.org/rel_rate.htm
} 
of people in Latvia trusted the Church, in 1999 - 67 per cent and in $2008-62$ per cent of the population trusted the Church. This data is significant especially when compared to trust levels in other institutions, e.g. in 2008 only 21 per cent trusted in the government, 20 per cent in the parliament, and 14 per cent in political parties. Correlation calculations show that those who believe in God also tend to trust the Church, same as those who trust in political parties, also trust in government and parliament.

These public opinion studies also show that people in Latvia, same as in other Eastern European countries tend not to trust other people, which does not allow for personal trust levels to spill over to trust in political institutions. These factors cause great concern not only for a successful democratic consolidation, but also hinder the political processes in the country, which causes many politicians to seek the help of local churches and their clergy in an attempt to raise general trust levels.

If we look at the historic development of Church and State relations, we see that it has always been characterised by competition between these two spheres, and for this reason their mutual separation is considered to be a sign of modernism. In order to understand institutional Church and State relations, we must understand the different interests of religious institutions and secular actors. The role of religious leaders primarily is to attract as many followers as possible, as well as to draw them to a particular system of beliefs or doctrine. ${ }^{3}$ One of the most effective, but at the same time difficult methods is to religiously socialise society members. ${ }^{4}$ Thus both parties find mutual benefits in their relationships, which despite separation of Church and State do not necessarily mean separation of politics and religion. In many countries, religious leaders play an important role in political mobilisation of the society,

\footnotetext{
3 Anthony Gill, "The Economics of Evangelisation," in: Evangelisation and Freedom in Latin America, ed. Paul Sigmund (Maryknoll New York: Orbis Books, 1999), 8

${ }^{4}$ Laurence Iannaccone, "Religious Practice: A Human Capital Approach," Journal for the Scientific Study of Religion, Vol. 29, No 3 (1990):314
} 
and they are able to call them to take collective action. This desire for the support of the Church of the secular state may be traced back to Charlemagne and the Holy Roman Empire. However, this relationship exists on a certain amount of hypocrisy, because, regardless of the circumstances, the Church and the State are opponents who only occasionally tend to work together for the mutual benefit of their relations. Absolute power always belongs to one or the other - either to the Church or to the State, depending on which is stronger.

Political scientist Anthony Gill who has done extensive research on religion and politics points out three areas which, in his opinion, nowadays are fundamentally important both to the Church and to the State - education, taxes and laws (Gill \& Heshavarzian 1999). In his opinion, religious leaders have an interest in controlling the educational system, or at least part of it, in order to teach religious norms and beliefs. The State requires the same, because it wants to impact education and raise children as loyal and politically active citizens, and to ensure political stability. Even though historically churches were responsible for collection of taxes, nowadays this role is maintained exclusively by the State, even when it actually affects the finances of the Church, e.g., fees for wedding ceremonies, funeral services etc. ${ }^{5}$ However, the Church would want to retain certain privileges - and in many countries they do receive tax deductions and other benefits from the State. As the number of attendees continues to decline and thus reduces the financial resources, churches are forced to appeal to the public to ensure their physical existence. Laws are important to any government, as they help exercise power on political, economic, and social issues. It would seem that churches in modern states have no saying in this field whatsoever, but as it turns out, this is one of the fields where churches are trying to retain most of their influence, since a number of issues, which are usually associated with ethics and morality, are of great

\footnotetext{
${ }^{5}$ Anthony Gill and Arang Heshavarzian, "State Building and Religious Resources: An Institutional Theory of Church-State Relations in Iran and Mexico," Politics \& Society, Vol. 27, No 3 (SAGE Publications, September 1999): 440
} 
importance to them. Through religious education and mass media as well as Christian politicians, churches have been able to express their opposition on such issues as legalisation of homosexual rights, abortion, euthanasia and other.

Even though the Church has officially moved in the background, it regards the prevalence of certain privileges and zones of influence of utmost importance. The Catholic Church in particular continues to retain a strong, important and active presence in the lives of many members of society. ${ }^{6}$ At the same time, Protestant churches encourage their members to a personal attitude towards religion, thus leaving it up to the individuals to decide what moral codes to follow, while stressing that their personal beliefs must manifest in the society and community around them. Thus we can conclude that the political activity of the Catholic Church is vertical - the top hierarchy of the Church makes politics through formal "partnership agreements" with the State, whereas Protestant churches use their horizontal links, allowing and even encouraging the laity to actively participate in politics. It is debatable as to which of these methods (vertical or horizontal) is more influential, but it is clear that the Church as an institution remains a significant contender for political power.

\subsection{Theoretical Aspects of Political Behaviour of Clergy}

Differences in attitudes towards the clergy as an institutional body, also creates a different attitude from the Churches as to what the role of clergy is in the society and in politics.

Before we start any attempts at the classification of political behaviour and socio-political activity of clergy, we need to return to the classics of political science - theories of political behaviour and political participation. Scientific studies in political science about political participation traditionally have focused on the participation levels of the entire society, less attention

\footnotetext{
${ }^{6}$ René Rémond, Religion and Society in Modern Europe (Oxford: Blackwell, 1999), 24-26
} 
paying to individual groups and their political activities. However, Sidney Verba et al. studies in the 90 s found that a variety of professional groups display "different configurations of participatory factors and levels of activity" (Verba, Schlozman \& Brady 1995). Based on their theories, four key elements become essential to political activity: (1) personal resources, including socioeconomic factors, (2) professional ideology, (3) mobilization, and (4) organizational activity.

According to the theory of clergy political behaviour (Crawford \& Olson 2001), when we consider the political behaviour of clergy, one of the primary socio-political factors is gender. Clergy is still one of the rare professions, which is predominantly male, since women constitute a minority (depending on country and denomination, women clergy range from 0 to 20 per cent); however, women clergy tend to be politically more active than their male colleagues. The second factor is race - though this factor is more dominant in the US where Afro-American clergy are socio-politically more active than their colleagues of other races. It is also interesting to note that the socio-economic situation of the clergy is only a partially detrimental factor, as it can affect, but not necessarily does affect the political behaviour of clergy. If the Church is located in a disadvantaged district with high levels of crime, clergy may decide to get involved in order to change the situation. For this reason it is always important to consider the location of a church when studying clergy behaviour. Fourth, general national political context is important as it determines what the possibilities for clergy to actually influence socio-political processes in their country are. It should be noted here that it is always easier for hierarchical religious institutions as the Catholic Church and the Orthodox Church to do it.

In addition to the mentioned above, another catalyst of socio-political behaviour is personal charisma, which is a tricky factor. Theory states that clergy, who are charismatic, are able to formulate political questions in a confident way and thus they are more successful at mobilising their church 
members for political action. ${ }^{7}$ For many years it was believed that age is the primary factor of political activity - the older the clergy, the more politically active they are and gain support, however, recent research shows that this is not necessarily the case. On the contrary, the younger the clergy, the more politically active they are. ${ }^{8}$ Considering the fact that clergy come from a variety of classes, they also acquire various levels of education - many of them even lack higher education. In order to become a member of the clergy religious institutions always do not require higher theological education. This is particularly true in Central and Eastern European countries, where particularly during the Soviet era it was difficult to acquire any theological education whatsoever, which also resulted in a deficit of clergy. Income can also be a contributing factor even though it differs greatly, depending on various reasons from country or denomination specifics to the size of the congregation.

What Sidney Verba et al. in the theory of political behaviour defined as professional ideology in the context of clergy may be defined as their theological beliefs or denominational adherence. However, this is where we encounter the first methodological problem - theological beliefs and denominational adherence are not necessarily correlating factors. On the one hand they should be - when theological differences cause friction among groups, they split away and form new denominations, which then form their own theology. At the same time, reality shows that various theological views are present within the same denomination. Therefore it should be noted that denominational adherence is the larger framework (Catholics, Protestants, Orthodox, Evangelical Christians) according to which we can analyse the reasons for political behaviour of clergy, but we should always take into

\footnotetext{
${ }^{7}$ Sue E. S. Crawford and Laura R. Olson, "Clergy as Political Actors in Urban Contexts" in Christian Clergy in American Politics, ed. Sue E. S. Crawford, Laura R. Olson (Baltimore and London: The John Hopkins University Press, 2001), 13

${ }^{8}$ James Guth et al., "The Political Activity of Evangelical Clergy in the Election of 2000: A Case Study of Five Denominations," Journal for the Scientific Study of Religion, Issue 42, Vol. 4 (2003):511-512
} 
account the individual theological views of clergy, which can fluctuate from conservative to liberal.

Research on the political behaviour of clergy has clearly shown compatibility between mobilisation opportunities and the activity of their organisation (Hadden 1969, Quinley 1974). That is, their political activity is tightly connected to their theological views, their personal political beliefs and mobilisation opportunities. ${ }^{9}$ Scientists have used various terms to describe these three factors, but one of the most prominent is that put forward by Ted Jelen, who based his work on that of James Guth et al. (1997). Ted Jelen has put these principles into three categories: social theology, theological authority and political skills (Jelen 2001). Social theology is affected by theological beliefs and determines whether clergy who are politically active see a close connection between their pastoral work and secular politics. Social theology includes three subgroups:

1) Christian orthodoxy - what exactly are the theological views of clergy - whether they are conservative or liberal, therefore their attitude towards various theological claims is studied (Guth et al. 1997). The last two decades have shown that Evangelical clergy, which traditionally were religiously more conservative and who primarily were concerned about the salvation of souls, have started to involve in various socio-political activities in recent years. ${ }^{10}$

2) Civic gospel (Ted Jelen also calls this social gospel) is determined, by studying their attitude towards various social and political claims. Civic gospel connects theological views of clergy with their political

\footnotetext{
${ }^{9}$ James Guth et al., "The Political Activity of Evangelical Clergy in the Election of 2000: A Case Study of Five Denominations," Journal for the Scientific Study of Religion, Issue 42, Vol. 4 (2003):506

${ }^{10}$ Ted. G. Jelen, "Notes for a Theory of Clergy as Political Leaders," in Christian Clergy in American Politics, ed. Sue E. S. Crawford, Laura R. Olson (Baltimore and London: The John Hopkins University Press, 2001), 18
} 
participation levels. It shows to what extent they are open towards cooperation between Church and State.

3) Civic religion is measured to determine clergy's attitude towards claims like "Religion has a positive effect on social and political life." Whenever religion becomes a tool for the achievement of political ambitions, it becomes 'civic religion'.

Theological authority or theological beliefs are another variable, which determines the level at which clergy are ready to involve in sociopolitical processes. In the majority of cases clergy are not interested to go against the beliefs of their congregation members, especially in light of pluralism and religious competitiveness. Considerable differences may be observed between Protestants and Evangelical Christians on the one hand, and Catholics and Orthodox believers on the other hand on this issue.

Civic skills are always essential, because they help all members of the society to be socially and politically active. In line with political theories, it must be noted that political skills are a positive catalyst of political activities, and clergy are no exemption to this rule. Evangelical clergy are in a slightly worse position in this respect, because contrary to their Catholic and other colleagues from 'older' denominations, they have not attended prestigious higher education institutions, and in general they tend to have lower levels of education. ${ }^{11}$ But they tend to replace this with political skills, which, as research shows (Verba et al. 1995), are most commonly acquired in egalitarian low churches - in the ones where horizontal rather than vertical relations are popular, rather than it is in Catholic and Orthodox churches.

Another important factor of civic skills are modern technologies, which in many ways have made it easier, reducing the need for resources of

\footnotetext{
${ }^{11}$ James Guth et al., "The Political Activity of Evangelical Clergy in the Election of 2000: A Case Study of Five Denominations," Journal for the Scientific Study of Religion, Issue 42, Vol. 4 (2003):505
} 
political participation - political participation nowadays is much cheaper than it was a couple of years ago.

Modern technologies and the internet allows for various social networks to be used effectively to achieve social and political goals. These technologies also allow clergy effectively to participate in the political discourse. And thus the next question arises - how effectively can clergy transfer their socio-political behaviour into actual behaviour of their congregation members. Ted Jelen distinguishes a number of indicators: (1) Persuasion, which is effective, if the clergy member has been able to persuade members of his congregation about a unified political stance. (2) Agenda setting, which they can do to persuade members of their congregation about the importance of certain issues. If clergy members are able to set some issues in the agenda of the Church, in time it may result in specific actions. (3) Mobilisation follows after clergy members have successfully reached the goals in the issues listed above, and they have received a positive response, encouraging their congregation members to political activity. ${ }^{12}$

According to the 'standard socio-economic model' of political participation, socio-politically less active are those individuals, who lack socioeconomic resources to qualitatively participate in political processes, unless they have a strong group consciousness (Verba, Nie 1972).

*** $*$

Thus this chapter allows us to conclude that secularisation, which began in the 19th century along with modernisation, urbanisation and pluralism caused the development of individualism. Increasing pluralism in social life created pluralism also in the religious offer, thus causing competitiveness, modernising churches and as a result also increasing the number of adherents.

\footnotetext{
12 Ted. G. Jelen, "Notes for a Theory of Clergy as Political Leaders," in Christian Clergy in American Politics, ed. Sue E. S. Crawford, Laura R. Olson (Baltimore and London: The John Hopkins University Press, 2001), 25-27
} 
Institutional secularisation is more distinct than individual secularisation, which affects personal religious beliefs of people. This institutional secularisation and separation of churches from political and social processes increases the political activity of many clergy members, with the goal to maintain their institutional influence as much as possible (even though it has been irrevocably lost), and maintain moral values in the society. To a great extent this task is made easier by the high levels of trust in churches, thus allowing us to conclude that churches have strong potential to consolidate the fragmented society in Latvia as well as to promote trust increase in the society.

The political behaviour of clergy is determined by two primary variables: individual indicators (personal experience, which has been acquired through family and their church) and theological beliefs (social theology). Additionally other variables should be considered, such as socio-economic factors, theological authority and civic skills - in the form of resources and mobilisation opportunities. These are the primary criteria, which should be considered when researching the political behaviour of clergy and factors influencing their socio-political activity. 


\section{CHURCH AND STATE RELATION DEVELOPMENT IN LATVIA}

\subsection{Historical and Institutional Relations of Church and State in Latvia}

Separation of Church and State is considered the prerequisite of a modern state, as it promotes democracy, tolerance and pluralism, since the society is not compelled to the dominance of one religion or denomination. If we look at historic Church and State relations, Latvia differentiates as one of the few countries that has never had religious wars. And even though there have never been any notable problems between the two powers, the Church and State are still separated, as stipulated by Article 99 of the Constitution of the Republic of Latvia, which also envisions freedom of thought, conscience and religion. But in reality this issue is much more complex, because whenever one or the other party crosses the boundaries of the other, serious discussions follow. The Church continues to hold a certain amount of influence, associated with social and political processes, and it manifests itself in two dimensions - politically and socially institutional, and spiritually-individual.

When analysing the historic relations of the Church with the State, 20th century must be pointed out as the most prominent period, because ever since World War I, and consequential collapse of empires, and formation of national un sovereign states (including Latvia), there have always been Christian parties in the parliament, starting from the Constitutional Assembly and 1st Saeima (Parliament), most notably - Union of Christian Democrats, Christian People's Party and Christian Democratic Party, as well as many others, which even if they did not entail the word 'Christian', included clergy members as well as lay people.

Ringolds Balodis in his book 'State and Church' (2002) characterised Church and State relations in the Eastern block after World War II as 'uncertain'. In order to maintain good relations with allies, the USSR proclaimed freedom of religion, but it was only a facade, since after World War 
II a 50 year long period of repression started in Latvia, as well as in many Eastern European countries, which manifested as mass repressions as part of Stalinist policy. ${ }^{13}$

Restrictions of church activities in Latvia began already in 1944, when many churches lost their clergy and congregation members to persecutions. The totalitarian regime of the USSR practiced hostile politics and it was carried out by the Council of Religious Cult Affairs (CRCA). The goals of the Communist politics were to subject, separate and isolate the Church from the society, and to a great extent they managed to achieve this goal. The Soviet authorities greatly affected Baptist, Methodist, Adventist and Old-believer churches, which were much smaller with fewer followers and limited financial resources than the 'traditional' churches - Catholics, Lutherans and the Orthodox. Their church properties on many occasions were confiscated and at best given to the traditional churches, or were nationalised by the State. The inner structure of churches was also continuously being disrupted during the Soviet era. ${ }^{14}$

But as shown by Frans Hoppenbrouwers - researcher of Eastern European history and religion, starting with the 70s, the number of repressions decreased, and in the 80s authorities even allowed for certain commemoration events to take place. These were usually associated with feast days of the Catholic and Orthodox saints. ${ }^{15}$ Church activities continued to be strictly monitored and their activities were limited. As a result of activities sanctioned by Soviet authorities, by 1985 statistics showed a considerable decrease in the numbers of church members, but with the regaining of independence, revival began in all denominations. After 1989 upon acquiring freedom, people also wanted to renew the social role of the Church - Christian pre-schools and schools were opened, as well as the Faculty of Theology (1990). Churches put

\footnotetext{
${ }^{13}$ Ringolds Balodis, Valsts un baznīca (Rīga: Nordik, 2002), 324

${ }^{14}$ Frans Hoppenbrouwers, "Romancing Freedom: Church and Society in the Baltic Sates since the End of Communism," Religion, State \& Society, Vol. 27, No. 2 (Routledge, 1999), 171

${ }^{15}$ Ibid., 165
} 
issues on social activities, charity, access to media, involvement in political life and financial support back on their agendas. Many churches became very active. The ones that received support from sister churches in the West primarily Germany, Sweden, the UK and the US turned out to be particularly successful. Thus we can conclude that in general, the beginning of 90s may be considered as a positive time in the life of churches, but already in the mid-90s churches began to experience the downfall of revival euphoria. In many churches the number of attendees considerably decreased, and they had to face many problems. The 21 st century does not allow for common trends in church development to be set.

If we look at Church and State relations from the institutional perspective, we can see that these relations are not entirely defined and in many ways continue to be uncertain. When trying to define Church and State relations in the Constitution, it was decided to note that Latvia is a secular country, and the paragraph about the separation of Church and State should be retained, and therefore none of the Churches was proclaimed as principal. Article 99 of the Constitution of the Republic of Latvia declares anyone's rights to the freedom of thought, conscience and religious beliefs, and also specifies that the Church (any religious organisation) is separated from the State. Respectively the State along with its official institutions must be neutral towards religious denominations. However, this Article does not solve all problems between the Church and State, primarily because already in the 90s the larger and 'traditional' denominations wanted to strengthen their position, and started the discussion as to which denomination are, and which ones are not authorised to perform marriage ceremonies. They also stated a discussion on terms 'traditional religions' and 'traditional denominations'. Despite their efforts, these terms have not been defined up until now. The 'Law on Religious Organisations' does not even contain a definition of what non-traditional denominations or new religious movements are, and what the State's position 
towards them is. This aspect has caused problems between the so called traditional and non-traditional churches, encouraging the former to sign individual agreements with the State defining their individual spectrum of relations. The Holy Sea was the first to sign an agreement (but not a concordat) with the Republic of Latvia on 12 September 2002 thus substituting the concordat from 30 May 1922 between the Holy Sea and the government of Latvia. All the consequential agreements signed until 2007 with the traditional churches have a similar structure and only partially differing statements.

Church and State relations in the 20th century have gone through essential and dynamic changes. Despite discussions about secularisation and its tendencies, the majority of traditional Christian denominations are authorised to hold religious teaching classes in schools and in general they have been granted an important role in the society in Latvia - traditional denominations are recognised and all of them have signed contracts with the State, defining their scope of activity.

\subsection{Political Activities of Clergy in Latvia}

As of 2002, when Latvian First Party was elected in the 8th Saeima, a new term has appeared in the political arena of Latvia, namely - Christian politics, which by its proponents was promoted as necessary on the grounds of general moral and spiritual downfall, thus several clergy members saw the necessity to form a new political power. However, if we look at history and the political behaviour and socio-political activity of clergy, we can see that a variety of lay members and clergy have always participated in Latvian politics. As pointed out by the historian Indulis Zvirgzdiñš - in the 19th century Lutheran, Catholic and Orthodox churches in parallel to religious functions also at least partially administered public functions, ensuring the reading of various 
laws and regulations, organised school work, medical and postal services. ${ }^{16}$ Many of the political ideas also could be heard in churches (appeals, ,church demonstrations" etc.). Second, we should remember that in the 19th century churches became the forges of nationalist ideas. It is only natural that many clergy members also addressed various political issues in order to promote national and spiritual ideas that they supported.

When we look at the political behaviour of clergy in Latvia, the controversial political figure and Lutheran pastor Andrievs Niedra who in the end was convicted of treason can be seen as one of the first examples. However, when we analyse democratic institutions, we see that as soon as the political situation in Latvia stabilised, the role of clergy also changed and they started a democratic competition for power and representation rights.

In the Constituent Assembly one Catholic prelate, two Lutheran pastors and one rabbi Aaron Bar Nurok were elected. Whereas the largest number of clergy members was represented in the 1st Saeima, where in total there were 10 clergy members; in the 2nd Saeima seven, in the 3rd Saeima nine and in the 4th Saeima eight.

The list of all clergy members represented in the Constituent Assembly and 1st through 4th Saeima, as well as their political affiliations are shown in Table 2.1 (next page). If we look at historic sources for the parliamentary composition of pre-war Latvia, we see that in 1922, 12 MPs were elected in the 1st Saeima from the so called Christian parties: Latgale Christian Peasantry Union (6), Christian National Union (4), Zemgale Catholic list (1), Oldbeliever Central Committee (1).

In 1925, the total number of Christian parties in the 2nd Saeima had grown from four to five, and the number of MPs to 13. In 1928, the elected MPs

\footnotetext{
16 Indulis Zvirgzdinš̌, „1905. gads Lazdonas draudzē.” Raksts no starptautiskas konferences „Informācija, revolūcija, reakcija: 1905-2005,” Materiālu krājums, Rīga: 2005. gada 23.-25. novembris, http://academia.lndb.lv/xmlui/bitstream/handle/1/651/indulis_zvirgzdins_1905_ gads_lazdonas_draudze.pdf?sequence=1, 141
} 
continued to form new political parties, thus increasing the number of Christian parties in the 3rd Saeima to 6, and the number of MPs to 17. In addition, the 3rd Saeima can be noted as the only time when two rabbis were elected - Aaron Nurok and Marcus Nurok from the Zionist organisation "Mizrachi". The 4th Saeima showed first signs of institutionalisation of political parties - the titles of Christian parties remained as they had been in the 3rd Saeima, and clergy MPs were also basically the same, whereas the number of "Christian" MPs was the largest in all Saeimas (18). It should also be noted that among many other activists, politicians and city mayors, two Lutheran pastors were Ministers of Education - pastor Pauls Gailitis (27 January — 19 June 1923) and pastor Kārlis Beldavs (18 March — 15 May 1934).

Table 2.1

Lutheran, Catholic, Baptist, Orthodox an Judaist clergy elected in the Constituent Assembly of the Republic of Latvia and 1st through 4th Saeima

\begin{tabular}{|c|c|c|c|c|}
\hline $\begin{array}{l}\text { Constituent } \\
\text { Assembly }\end{array}$ & 1st Saeima & 2nd Saeima & 3rd Saeima & 4th Saeima \\
\hline 1920 & 1922 & 1925 & 1928 & 1931 \\
\hline $\begin{array}{l}\text { Francis Trasuns } \\
\text { (LKZS), prelate }\end{array}$ & $\begin{array}{l}\text { Bernards Kublinskis } \\
\text { (ZKS), bishop }\end{array}$ & $\begin{array}{l}\text { Bernards Kublinskis } \\
\text { (KKZP), bishop }\end{array}$ & $\begin{array}{l}\text { Alfons Pastors } \\
(\mathrm{KZKF}) \text {, dean }\end{array}$ & $\begin{array}{l}\text { Alfons Pastors } \\
\text { (KZKF), dean }\end{array}$ \\
\hline $\begin{array}{l}\text { Kārlis Irbe } \\
\text { (KNS), dean }\end{array}$ & $\begin{array}{l}\text { Jezups Rancāns } \\
\text { (LKZS), bishop }\end{array}$ & $\begin{array}{l}\text { Alfons Pastors } \\
(\mathrm{KKZP}) \text {, dean }\end{array}$ & $\begin{array}{l}\text { Jezups Rancāns } \\
\text { (KZKF), bishop }\end{array}$ & $\begin{array}{l}\text { Jezups Rancāns } \\
\text { (KZKF), bishop }\end{array}$ \\
\hline $\begin{array}{l}\text { Kārlis Kellers } \\
\text { (VDP), pastor }\end{array}$ & $\begin{array}{l}\text { Francis Trasuns } \\
\text { (LKZS), prelate }\end{array}$ & $\begin{array}{l}\text { Jezups Rancāns } \\
\text { (KKZP), bishop }\end{array}$ & $\begin{array}{l}\text { Kārlis Beldavs } \\
\text { (KASF), pastor }\end{array}$ & $\begin{array}{l}\text { Kārlis Beldavs } \\
\text { (KASF), pastor }\end{array}$ \\
\hline $\begin{array}{l}\text { Arons Bars Nuroks, } \\
\text { (ŽBG), rabbi }\end{array}$ & $\begin{array}{l}\text { Paulis Gailitis } \\
\text { (LZS), pastor }\end{array}$ & $\begin{array}{l}\text { Francis Trasuns } \\
(\mathrm{LgDP}), \text { priest }\end{array}$ & $\begin{array}{l}\text { Jēkabs Kullits } \\
\text { (KASF) pastor }\end{array}$ & $\begin{array}{l}\text { Visvaldis Sanders } \\
\text { (KASF), pastor }\end{array}$ \\
\hline ( & $\begin{array}{l}\text { Teodors Grīnbergs } \\
\text { (KNS), bishop }\end{array}$ & $\begin{array}{l}\text { Jānis Ģībietis } \\
\text { (LZS), pastor }\end{array}$ & $\begin{array}{l}\text { Visvaldis Sanders } \\
\text { (KASF), pastor }\end{array}$ & $\begin{array}{l}\text { Jānis Teriņš (KASF), } \\
\text { pastor }\end{array}$ \\
\hline- & $\begin{array}{l}\text { Kārlis Irbe } \\
\text { (KNS), dean }\end{array}$ & $\begin{array}{l}\text { Jānis Pommers } \\
\text { (PVKAOB), arhib. }\end{array}$ & $\begin{array}{l}\text { Ẽvalds Rimbenieks } \\
\text { (KDLS), pastor }\end{array}$ & $\begin{array}{l}\text { Ēvalds Rimbenieks } \\
\text { (KDLLS), pastor }\end{array}$ \\
\hline - & $\begin{array}{l}\text { Kārlis Kellers } \\
\text { (LVBP), pastor }\end{array}$ & $\begin{array}{l}\text { Markus Nuroks } \\
(\mathrm{COM}), \text { rabbi }\end{array}$ & $\begin{array}{l}\text { Jānis Pommers } \\
\text { (PVVAKOF), arhib. }\end{array}$ & $\begin{array}{l}\text { Jānis Pommers } \\
\text { (PVVAKOF), arhib. }\end{array}$ \\
\hline- & $\begin{array}{l}\text { Jēkabs Kullits } \\
\text { (KNS), dean }\end{array}$ & - & $\begin{array}{l}\text { Markus Nuroks } \\
(\mathrm{COM}), \text { rabbi }\end{array}$ & $\begin{array}{l}\text { Markus Nuroks } \\
\text { (COM), rabbi }\end{array}$ \\
\hline- & $\begin{array}{l}\text { Visvaldis Sanders } \\
\text { (KNS), pastor }\end{array}$ & - & $\begin{array}{l}\text { Arons Nuroks } \\
\text { (COM), rabbi }\end{array}$ & ( \\
\hline - & $\begin{array}{l}\text { Markus Nuroks } \\
\text { (ŽANB), rabbi }\end{array}$ & - & - & - \\
\hline
\end{tabular}

Source: Compiled based on Latvijas Satversmes Sapulces (1925) un LR Saeimas Stenogrammas. Rīga: LR Saeimas izdevums, 1922, 1925, 1928, 1931.

\begin{tabular}{|l|l|l|l|r|}
\hline Catholic & Lutheran & Baptist & Orthodox & Judaist \\
\hline
\end{tabular}

COM - Zionist organisation "Misrachi", KASF - Christian Union and Worker's Fraction, KDL,S - Christian Worker's Union, KKZP - Catholic and Christian Peasantry Party, KNS - Christian National Union, KZKF Christian Peasantry and Catholic Fraction, LgDP - Latgale Democratic Party, LKZS - Latgale Christian Peasantry Union, LVBP - Latvian Baltic German Party, LZS - Latvian Farmer's Union, PVKAOB - United Organisation Block of Orthodox Voter and Russians, PVVAKOF - United Russian Organisation and Orthodox and Old-believer Voter Fraction, VDP - German Democratic Party, ZKS - Zemgale Catholic List, ŽANB United National Jewish Block, ŽBG - Jewish Non-partisan Group. 
If we compare 5th through 11th Saeima to the pre-war Saeimas and the number of clergy members elected in the parliament, we can see that there is a notable difference in the number of elected clergy MPs, since it is never more than three clergy members. The second characteristic is that since regaining independence, neither Catholic, nor Orthodox or Judaist clergy members have been elected in the parliament (see Table 2.2).

Table 2.2

Lutheran and Baptist clergy elected in the 5th through 11th Saeima

\begin{tabular}{|c|c|c|c|c|c|c|}
\hline 5th Saeima & 6th Saeima & 7th Saeima & 8th Saeima & 9th Saeima & \multicolumn{2}{|c|}{ 10th and 11th Saeima } \\
\hline 1993 & 1995 & 1998 & 2002 & 2006 & \multicolumn{2}{|c|}{$2010-2011$} \\
\hline $\begin{array}{l}\text { Olafs Brūvers } \\
\text { (LKDS) }\end{array}$ & $\begin{array}{l}\text { Olafs Brūvers } \\
\text { (DPS) }\end{array}$ & $\begin{array}{l}\text { Aida Prēdele } \\
\text { (TB/LNNK) }\end{array}$ & $\begin{array}{l}\text { Ainars Baštiks } \\
\text { (LPP) }\end{array}$ & $\begin{array}{l}\text { Ainars Baštiks } \\
\text { (LPP/LC) }\end{array}$ & \multicolumn{2}{|l|}{-} \\
\hline $\begin{array}{l}\text { Andris Grots } \\
\text { (LKDS) }\end{array}$ & $\begin{array}{l}\text { Modris Plāte } \\
\text { (L) }\end{array}$ & - & $\begin{array}{l}\text { Jānis Šmits } \\
\text { (LPP) }\end{array}$ & - & \multicolumn{2}{|l|}{-} \\
\hline $\begin{array}{l}\text { Aida Prēdele } \\
\text { (LKDS) }\end{array}$ & $\begin{array}{l}\text { Aida Prēdele } \\
\text { (LZS) }\end{array}$ & - & - & - & \multicolumn{2}{|l|}{-} \\
\hline $\begin{array}{l}\text { Source: Con } \\
\text { Commission }\end{array}$ & $\begin{array}{l}\text { ed based on } \mathrm{d} \\
\text { Latvia } W w W\end{array}$ & from the $h$ & & Election & Lutheran & Baptist \\
\hline
\end{tabular}

DPS - Democratic Party "Owner", L - People's Movement "For Latvia”, LKDS - Latvian Christian Democrat Union, LPP - Latvian First Party, LPP/LC - Union Latvian First Party and Party "Lavia's Way", LZS - Latvian Farmer's Union, TB/LNNK - Union "For Fatherland and Freedom"/LNNK

Upon restoration of independence, an American-Latvian Baptist pastor Olafs Brūvers and Lutheran pastor Aida Prēdele were elected in the 5th Saeima, and after Aivars Jerumanis (LKDS) put down his mandate, he was replaced by American Latvian, Lutheran pastor Andris Grots. In the 6th Saeima Olafs Brūveris and Aida Prēdele (initially from KDS, later from TB) were joined by Lutheran pastor Modris Plāte, however, Pauls Kl̦aviņš and Māris Vītols should also be mentioned - even though they were not clergy members, they were portrayed in the media as church representatives. In the 7th Saeima only Aida Prēdele and Māris Vītols were left, however, Lutheran pastor Guntis Dišlers became the head of the newly established New Christian Party. This coincided with the notable popularity decrease of the Latvian Christian Democrats who lost their voter support. The New Party, which was elected in the 7th Saeima with 7.3\% in 2001 was renamed The New Christian Party, and can be considered the predecessor to Latvian First Party, also known as "pastors' 
party”. Even though media portrayed the number of clergy in the 8th Saeima as notable, in fact, it included only two - Baptist pastor Ainars Baštiks and Lutheran pastor Jānis Šmits. Since regaining independence, several clergy members have been elected in local councils, becoming even chairmen, including, Baptist pastors Valdis Obersts in Jaunjelgava, Aivars Šķuburs in Talsi, Artūrs Šķuburs in Liepāja and Lauris Karlsons in Mērsrags. A notable difference appears with Methodist and Adventist clergy, which so far have never held any political positions probably due to their small size.

Political offices during the pre-war period in Latvia were occupied by several Catholic clergy members. If the present Canon Codex 285.3 of the Catholic Church prohibits clergy from having positions in the civil society, then even though the Codex of 1917 in Canon 139 advised clergy members to avoid such activities, with the consent of local bishops could get involved in political activities. Therefore, when Latvia was founded as an independent country in 1918, one of the most notable aspects was that "Catholic clergy [were] allowed to work in political parties and in the Parliament of Latvia". ${ }^{17}$

The relationship of the Orthodox Church with the State of Latvia has always been difficult, because the Orthodox faith has always been associated as a "Russian religion", thus adding a complicated factor of nationalism. During the interwar period the attitude towards LOC was suspicious and in general condemning - many Orthodox religious institutions were closed, many properties were seized and given over to Catholics and Lutherans, or simply destroyed. ${ }^{18}$ As a result of these events LOC made the decision to have their representative in Saeima and thus promote legalisation of LOC in Latvia. These efforts resulted with the election of LOC archbishop Jānis Pommers in the 2nd Saeima. Since regaining of independence Orthodox clergy have never been

\footnotetext{
17 Vladislavs Malahovskis, „Katoḷu Baznīcas politiskās aktivitātes neatkarīgajā Latvijā,” Via Latgalica, Vol. 2 (Rēzeknes Augstskolas Reǵionālistikas institūts, 2009):80

${ }^{18}$ Jānis Kalniņš, Svētais Rīgas Jānis (Rīga: Jumava, 2001), 106
} 
elected in any of the Saeimas (the only Orthodox clergy member Aleksejs Zotovs was elected in the Supreme Council of the Republic of Latvia in 1990).

The old-believers can be characterised as one of the most isolated Christian denominations in Latvia. Since the restoration of independence no old-believer clergy member has actively involved in politics, however quite a few old-believer laymen have been elected in Saeima as well as local municipalities. In the local elections of Rīga Council in 2001 the Russian Party was striving for power, and the majority of their candidates were old-believers and the Orthodox. The most prominent old-believer political representatives are Ivans Ribakovs (8th through 11th Saeima MP), Ivans Klementjevs (9th through 11th Saeima MP, Rīga City Council deputy), and head of Rēzekne Old-believer Cemetery Church Council Vladimirs Nikonovs (10th through 11th Saeima MP). Pjotrs Aleksejevs - board member of Rīga The Emergence of God Pomorian Old Believers Church and director of the Institute of Old Believers in Latvia participated in the elections of the 11th Saeima from Šlesers Reform Party, but was not elected. ${ }^{19}$ Even though POBCL clergy members of all the analysed denominations officially do not participate in political processes and representation of their electorate, we cannot conclude that they are withdrawn from political and social processes altogether.

$* * *$

Summarising the analysis of the historic political behaviour of protestant clergy in Latvia we must conclude that during the pre-war period clergy formed approximately $10 \%$ of all MPs and more than half of those or 17 of 38 were Lutheran (7) and Baptist (2) clergy members. It should be noted that they were more active in the first four Saeimas, in comparison to 5th through 11th Saeima, which can be associated with the following factors: First, clergy were among the most educated members of the society during the pre-war

\footnotetext{
${ }^{19}$ Jesajas61.lv „Kandidāti. Pjotrs Aleksejevs.” Portāls Jesajas61.lv, www.jesajas61.lv/lv/kandidati/pjotrs_aleksejevs
} 
period, who enjoyed public trust as representatives of the people. That is a reason why many of them were town mayors and active members of the society. Second, they had wide opportunities for mobilisation, which can be explained with the social traditions of that period, when the majority of society regularly attended Sunday services. This allowed the clergy to expose church attendees to their rhetoric, including political canvassing. Third, the situation has changed considerably from the institutional point of view, since the 5 per cent electoral threshold did not exist at the time, and allowed for easier entry in the parliament. Ever since the 5 per cent electoral threshold was introduced we can see that even though a notable number of clergy have strived to be elected, they have not succeeded, as their political party has not received the necessary support from the society.

If we look at the socio-political activity of Catholic and Orthodox clergy we see that priests Francis Trasuns and Jezups Rancāns, as well as archbishop Jānis Pommers were notable personalities and part of the intelligentsia of that period, which managed to muster broad masses around themselves, thus becoming part of the political elite, who actively promoted the interests of their denominations. In general, it may be concluded that Catholic clergy involved in political processes to gain their personal interests, thus creating a healthy competition; whereas the Orthodox - deliberately promoted a representative in order to protect the interests of the Orthodox Church in Latvia. Old-believer clergy have stood apart from politics since the 20s, allowing their lay members to involve in politics.

Since the restoration of independence, only Protestant clergy members have been elected in Saeima, and they as well as lay members started their political activities still during Soviet occupation, when various dissidents and activists gained support in churches. Since the restoration of independence no more than three clergy members have been elected simultaneously in Saeima, and in the last two Saeimas clergy members have not been elected at all. 


\section{POLITICAL BEHAVIOUR OF CLERGY IN LATVIA}

\subsection{General Characterisation of the Socio-political Behaviour of Clergy: 2002-2012}

The agenda of mass media comparatively often include the political views of Christian clergy, and occasionally also their political behaviour. In most cases these are associated with various important political processes that have taken place in Latvia. However, there are cases when media have reported on political canvassing, which has taken place in one or another country. Thus it can be concluded that many pre-war traditions continue to exist and Christian churches in Latvia by no means are apolitical, since clergy choose to share their opinions during political campaigns, sometimes even encouraging churchgoers to vote for specific political parties.

If we look at how the political behaviour of clergy has been covered in the last 10 years in media, we can identify a dual representation in articles until 2006 articles mostly concentrate on political canvassing initiated by politicians and political parties. Whereas after 2006 whenever political canvassing is mentioned in the Churches of Latvia, it is initiated by clergy. Naturally this is a very controversial issue because even when initiated by political party members, they would have to receive acceptance of local clergy, thus we have to talk about clergy as at least passive supporters of political canvassing also prior to 2006.

\section{Political canvassing initiated by political parties and their} members: In December 2001, the media reported a case when chairman of New Era Einars Repše prayed about upcoming Saeima elections from the pulpit of Jēkabpils St Michael's evangelical Lutheran church. This was one of the first publically known cases after independence when political actors used the pulpit as a megaphone for the promotion of their political activities. The situation with Einars Repše in the same church repeated in 2004 prior to European Parliament 
elections. ${ }^{20}$ However other similar situations may be listed: prior to 8 th Saeima elections members of New Era went to the Dome Cathedral, where they swore an oath that they would serve the people of Latvia, act in accordance with the laws of Latvia and follow Christian values. Prior to 8th Saeima elections Latvian First Party used the image of the Church to popularise their party by inviting cardinal of the RCCL Jānis Pujats to speak in their founding congress. During Christmas 2004, newspaper Diena reported that attendants of Rìga John's evangelical Lutheran church had the opportunity to meet with Saeima MPs Jānis Šmits and Inta Feldmane after the service. These two MPs on several occasions have addressed also members of the Orthodox Church in Pārdaugava Trinity Church. Similarly also political party TB/LNNK sought support from Christian churches. Diena reported that on the information board of Baltinava Catholic church was a message that said: "Political party TB/LNNK are our people, because they have donated LVL 5,350 for the Church building project." ${ }^{21}$ Shortly afterwards prior to the local elections of 2005 also Latvian Way used the image of Dole-Ķekava Lutheran church building in their electoral campaign materials. And prior to 10th Saeima elections political union "For a Good Latvia!" continued to use their collaboration with churches by taking advantage of all the issues that had been set by churches, and that they knew they would be able to receive the support of Christian leaders.

When Jānis Šmits was once asked, whether politicians approach clergy or clergy approach politicians, he pointed out that clergy members of various churches invite politicians to their churches. The archbishop of ELCL also agreed with this and said he saw it as a regularity, because "this party [LPP] improved the fate of many churches, and sacral tourism has received great support in Latvia"22, additionally churches have their own interests, which they

\footnotetext{
${ }^{20}$ Santa Raita, „Baznīcu izmanto politiskajās cīṇās.” Neatkarīgā Rīta Avīze. 2004. gada 20. aprīlis, 1

${ }^{21}$ Anna Rancāne, Ināra Egle, Dita Arāja, „Politiķu slavināšanai izmanto dievnamu.” 23.12.2004. Diena. http://www.diena.lv/arhivs/politiku-slavinasanai-izmanto-dievnamu-12260308

${ }^{22}$ Ibid.
} 
hope to solve by approaching parties. However, this issue is ambiguous, because there have also been reports, when political parties have approached church leaders and clergy requesting to allow them to speak in their churches. ${ }^{23}$

Political canvassing initiated by clergy: As noted before, political canvassing in churches became less prominent as of 2006, and there were ever fewer politicians who promoted their actions and rather it was the clergy that encouraged people to participate in the elections. It is difficult to pinpoint what exactly the cause for this might be - it is possible that the media chose to report political canvassing in churches from another perspective, or the majority of clergy were disappointed by the actions of LPP, and therefore decided against supporting one particular political power.

Prior to the elections of 9th Saeima in 2006, media reported on several cases of political canvassing in churches, primarily reporting on clergy that had encouraged people to vote for parties that support Christian values, and in several cases even indicating for which party they should be voting for.

$* * *$

By using Lursfot periodical database, the analysis shows that there is a connection between clergy in Latvia and state representatives that affects various fields of life, including political and social life, however, clergy interest may be divided on four specific issues, based on agenda analysis:

First, Christian values - a term that the Churches are interested in, however, have never specified its meaning, and most commonly includes the rest of the three themes. Interest expressed by all denominations. Second, family values - similarly to Christian values, family values are often juxtaposed to sexual minority issues and manifests in actions against homosexual rights (they are against granting homosexuals the same rights as heterosexual partners on such issues as marriage and child adoption). Only LOC and POBCL do not talk

${ }^{23}$ Anna Rancāne, Ināra Egle, Dita Arāja, „Politiķu slavināšanai izmanto dievnamu.” 23.12.2004. Diena. http://www.diena.lv/arhivs/politiku-slavinasanai-izmanto-dievnamu-12260308 
about supporting families in the media. USDALC, UMCL and POBCL are mute on issues against homosexual rights on marriage and child adoption.

Third, education issues - primarily affects the introduction of religious education in schools. This issue is publically not promoted by LOC and POBCL. Fourth, integration issues, which affect various national aspects and integration. On the one hand, all Christian denominations support promotion of tolerance, integration and building bridges among the divided groups within the society in Latvia. At the same time, this issue in particular shows that Christian denominations do not share the same opinions. LOC and POBCL associate this issue to a great extent with the introduction of Orthodox Christmas holidays, as well as express their support in introducing two official languages in Latvia and granting of citizenship to non-citizens, whereas all the other Christian clergy members disagree with this opinion.

\subsection{Political Behaviour of Clergy in Latvia: Empirical Study}

\subsubsection{Conceptual and Methodological Justification of the Empirical Study}

The empirical study of the promotional thesis is based on the theoretical findings of Sidney Verba, Kay Schlozman and Henry Brady regarding the political behaviour of various professional groups. Their ideas are supplemented with the theoretical principles of political behaviour of clergy from authors like James Guth, Ted Jelen and other, and they are adapted for carrying out a study about the political behaviour of clergy in Latvia. Thus the following criteria are put forward as the most important factors determining

political behaviour: (1) Personal resources or socioeconomic factors. (2) Professional ideology - denomination and theological beliefs. (3) Mobilisation - size of the Church as important criteria, which allows clergy to call church members and attendants to political behaviour and actions. (4) Organisational activity or political behaviour within their professional framework as well as 
outside of it. This will allow us to identify the political behaviour and sociopolitical activity of clergy (H1), factors, which determine their political behaviour $(\mathrm{H} 2)$ as well as factors which stimulate their political behaviour $(\mathrm{H} 3$ and $\mathrm{H} 4)$.

Methodology: A quantitative method (surveying) was used in the empirical study in order to test the hypothesis and achieve the aims of the thesis. Quantitative data aggregation and operationalization allowed determining the political behaviour of clergy in Latvia and factors, which influence it. Since the field (specific denominations) and object (clergy) of the thesis is strictly defined within this study only their political behaviour is being studied, and with the help of correlations the factors determining their political behaviour are sought.

Sampling methods and size: The quantitative study was carried out by sampling the target population according to stratified sampling in order to compare the political behaviour of clergy of traditional denominations in Latvia. Within the time period when the study was carried out there were 209 clergy member in ELCL, 166 in RCCL, 97 in LOC, 88 in UBCL, 36 in POBCL, 29 in USDALC and 11 in UMCL, thus initially the general sample size was $\mathrm{N}=636$. Since the size of the sample is numerically small, the goal was to survey as many clergy members from Latvia as possible. In order to survey all respondents, the questionnaires were distributed to the clergy members through the synods of each respective Church. Only the leadership of RCCL and LOC refused collaboration. After examining the contents of the questionnaire Aleksijs Žilko (Chairman of the Central Council of POBCL) indicated that several questions were unacceptable. Thus for the POBCL a revised questionnaire was developed, which did not include any questions about the finances of the clergy or their churches. However, even though he agreed to collaborate in the survey, and requested that all questionnaires be sent to him for further distribution, no responses were received back from the old-believer 
clergy, and since their contact information is not available, POBCL clergy had to be excluded from the quantitative study. The Synod of LOC after examining the contents of the questionnaire refused any collaboration, and in a personal meeting with the Secretary of the Synod of LOC - hegumen Jānis (Sičevskis) indicated that LOC does not wish for their clergy to be surveyed and the activities of LOC in Latvia to be studied. Since their contact information is not available, LOC clergy also had to be excluded from the quantitative study.

The quantitative study on the political behaviour of clergy in Latvia was carried out from October 2011 until Jun 2012, using a quantitative survey with MCQs and open questions (structured surveying). In cases when questionnaires were filled in electronically (ELCL, UBCL, RCCL), the request to participate in the study was sent out twice within a two week interval. In total, 131 filled in questionnaires were received, which breaks down by denominations as shown in Table 3.1.

Table No. 3.1

General sample size and number of filled in questionnaires by clergy in the empirical study

\begin{tabular}{|l|r|r|r|}
\hline Denominations & $\begin{array}{c}\text { Clergy } \\
\mathbf{N}=\end{array}$ & $\begin{array}{c}\text { Filled-in } \\
\mathbf{n =}\end{array}$ & $\begin{array}{r}\text { Percentage of N } \\
\mathbf{\%}\end{array}$ \\
\hline ELCL & 209 & 58 & 27.8 \\
\hline RCCL & 166 & 13 & 7.8 \\
\hline UBCL & 88 & 31 & 35.2 \\
\hline SDALDS & 29 & 22 & 75.9 \\
\hline UMCL & 11 & 7 & 63.6 \\
\hline TOTAL & $\mathbf{5 0 3}$ & $\mathbf{1 3 1}$ & $\mathbf{2 6 . 0}$ \\
\hline
\end{tabular}

Source: Table by author, based on data acquired in the empirical study.

Since responses from LOC and POBL clergy were not recorded for the purposes of this study, the initial inter-denominational comparison of the political behaviour of clergy members could not be achieved just by using the quantitative method. Result representation was ensured by determining sample error and by weighing acquired results. If we assume that the levels of participation of Catholic clergy were low ( 7.8 per cent) and their responses cannot be included and interpreted as representative and trustworthy, then we 
can assume that the general size was $\mathrm{N}=337$ and population sample value was $\mathrm{n}=118$ (35.8 per cent). With a 95 per cent confidence at a fixed error $=0.05$, the confidence interval is 6.9. Despite the low levels of participation on part of the Catholic clergy their answers will be included in the study, however RCCL data should not be considered as representative, and they indicate only possible tendencies among Catholic clergy. The sample size of $n=118$ may be considered as sufficient. Data of the study was processed using IBM programme SPSS Statistics, Version 20.0.

Structure of the survey: The questionnaire consisted of an introduction, where respondents were introduced with the aim, rules, and confidentiality of the study. The questionnaire included: A) 19 MCQs, which strived to determine political behaviour and socio-political activity of clergy.

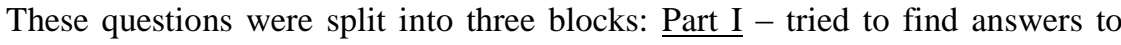
questions about the political culture and political behaviour of clergy, including questions on their political identification, conventional and unconventional forms of political participation as well as trust in various political institutions and other aspects of political culture (through affective and evaluative assertions about politics and religion, and Church and State relations in Latvia).

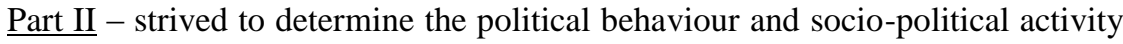

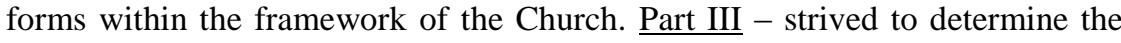
social theology of clergy. B) Two open questions on political identification, which helped to determine how parents have influenced the political behaviour of clergy, what their opinion and attitude of the political system is. The second question tried to determine the views of clergy on Church and State issues. C) Socio-demographic questions about the gender and age of clergy, location of their church etc.

Description of survey respondents: Since the survey compared the political behaviour of clergy from five Christian denominations in Latvia, the 
breakdown of respondents was as follows: $44.3 \%$ Lutherans, $23.7 \%$ Baptists, 16.8\% Seventh Day Adventists, 9.9\% Catholics and 5.3\% Methodists.

Gender: As far as clergy gender in Latvia is concerned, clergy are a homogenous group of people where $89.3 \%$ are male and only $9.9 \%$ female $(0.8 \%$ N/A). Gender will not be analysed as a determining factor of clergy political behaviour, since the number of female clergy members is statistically insignificant.

Age: $43.5 \%$ of clergy in Latvia are in the age group 31-45, followed by $46-60(37.4 \%)$ and $18-30$ year olds, which constitutes $12.2 \%$. Only $6.1 \%$ of respondents were in the age group 61-75, and only $0.8 \%$ were older than 75 . Which means the majority or $55.7 \%$ of clergy in Latvia are in the age group of up to 45 years. Percentagewise Catholic clergy are the youngest $(92.3 \%$ are 31 45 years old), followed by Baptists (22.6\% are 18-30 years old and $31.8 \%$ are 31-45 years old) and Methodists (42.9\% are 18-31 years old). Adventists have the oldest clergy (50.0\% are 46-60 years old) same as Methodists (28.6\% are 46-60 years old and $14.3 \%$ are 61-75 years old). Additionally it should be noted that the average time for clergy having served in churches is 11.8 years (std. deviation 8.3), which strongly correlates with clergy age $(\mathrm{r}=0.560)$.

Education: None of the clergy members who completed the questionnaire have only primary school education. 7.8 per cent of clergy admit to having secondary school education, whereas 31.0 per cent have graduated from a seminary, and 61.2 per cent indicated that they have graduated either from a university or a college. Answers to this question reveal that as far as education goes clergy in Latvia are a homogenous group as $92.2 \%$ have higher education, therefore their political behaviour will not be analysed by education.

Nationality: Since LOC and POBCL clergy did not participate in the study, as could be expected, the majority or 93.9 per cent of respondents were Latvian. Only one of the respondents was not a citizen of Latvia, and 5.3\% completed the questionnaire in Russian. Since a significant number of answers 
are missing from other ethnic groups and non-citizens, their political behaviour will not be analysed according to their nationality.

Socio-economic data: The majority of clergy or 45.8 per cent earn within a limit of LVL 200.00-350.00 per month, followed by 22.1 per cent who earn less than LVL 200.00 and 14.5 per cent who earn from LVL 350.00 to 500.00 per month. Only 4.6 per cent of clergy earn within a limit of LVL 500.00-650.00 and 5.3 per cent indicated that they earn more than LVL 650.00 per month net. In accordance with latest data, Catholic clergy have the lowest income (83.3 per cent earn less than LVL 200.00), whereas Baptist clergy have the highest income (12.9 per cent earn more than LVL 650.00).

Size of the congregation (number of attendants): The study shows that there are notable differences in the attendance amplitude in the churches of Latvia as the minimum number of people who attend services during weekend are 5, and the maximum is around 1000 attendants. Statistical average rate is 91 (std. deviation 130). Thus the income of the congregation is strongly linked to the number of attendants and their socio-economic situation $(r=540)$. The study shows that 81.4 per cent of congregations during weekend services are attended by less than 100 people, and in 52.4 per cent of cases churches are attended by less than 50 people. This shows us that mobilisation factors of clergy are insignificant for testing as this hypothesis could refer to a negligible percentage of clergy. Assuming that a "significantly" sized church (for mobilization purposes) would be one that regularly brings together over 500 people, or as a minimum of 200, it would apply only to 2.4 and 9.7 per cent of clergy in Latvia. Thus, based on the theoretical thesis of the behaviour of political behaviour that congregation size and clergy income have an insignificant role to play on the socio-political activity of clergy, size of the congregation hereafter will not be analysed as a determining factor of the political behaviour of clergy.

If we look at the socio-economic characterisation of congregation members we see that it is similar to the characterisation of clergy income. 52.8 
per cent of clergy indicate that their congregations are attended by people with low income, followed by 43.0 per cent of average income and only 4.1 per cent could be characterised as attendants with high income or unlimited means.

Location of the Church: The majority of surveyed clergy members serve in churches located in Latvian towns (41.2 per cent) and countryside (33.6 per cent); and only 23.7 per cent of those who filled in the questionnaire are from Rīga churches. Church location distribution is similar in the denominational aspect and thus data obtained are representative in the entire territory of Latvia.

Excluding denominational comparison and in addition to the socioeconomic indicators, further research will analyse the age of the clergy as well as location of the church as determining factors of political behaviour of clergy.

\subsubsection{Results and Analysis of the Empirical Study}

The aim of the questionnaire was to determine answers to four dominant groups of questions relating to the political behaviour and sociopolitical activity of clergy: (1) what is the political behaviour and socio-political activity of clergy of each denominational group, and how it manifests itself (H1) - this was determined by studying political culture and political participation of clergy; (2) what determines the political behaviour of clergy (H2) - analysing their activities by denomination, age and church location; (3) what factors stimulate the political behaviour of clergy (H3) - analysing their personal stance on issues of social theology; (4) to what extent their political behaviour is stimulated from the outside $(\mathrm{H} 4)$ - whether political party member or others associated with political powers encourage clergy to political activity.

Thus the first part of the questionnaire asked questions, which aimed at determining the political culture and political behaviour of clergy. The first question was a general one, and determined how interested clergy members are 
in politics. 56.5 per cent indicated that they sometimes follow political processes in the country, but take no particular part in them; 29.0 per cent said they regularly followed political processes, and quite often expressed their political views or even got involved in political processes. Only 1.5 per cent of respondents said they were not interested in political processes.

Further questions determined the political behaviour of clergy in conventional forms of political participation, primarily concentrating on participation in elections. Here clergy were asked to indicate all elections they had participated in since 2006. The results show that Baptist clergy (62.5\%), Lutheran clergy (64.2\%) and Methodist clergy (58.9\%) were most active, whereas Catholic and Adventist clergy (50.0 and 41.7 per cent respectively) were least active.

The next question asked whether they had ever voted for Latvian First Party or political unions LPP/LC or "For a Good Latvia". Contrary to popular belief, only 48.8 per cent of clergy had ever voted for LPP, and majority of them admitted $(72.1 \%)$ they had voted for LPP, because they had believed that they would implement "Christian politics". Only 11.5 per cent had voted due to other reasons: "I voted, because there were people I trusted", "Reasonable people ran for office in some counties" and "I voted for them, because it seemed the best option from all the offers".

Participation in elections is one of the most popular forms of political participation, because it requires least amount of resources, both in terms of finances and time, and knowledge. Precisely for this reason other forms of political participation are measured, e.g., participation in non-governmental organisations (NGO). Also in this field clergy demonstrated higher levels of participation -48.8 per cent are involved in NGOs, and that is 20 per cent more than on average in the society. 29.8 per cent of clergy are involved in at least one NGO, 13.7 per cent in two, and 3.8 per cent in more than two NGOs. Lutheran (53.5\%), Baptist (51.6\%) and Adventist clergy (50.0\%) are most 
active, whereas Catholic and Methodist clergy (76.9\% and 71.4\% respectively are members of none) are least active.

Political identification is another important factor in addition to socio-economic criteria as far as political participation is concerned, which is primarily determined by parents and family. 55.7 per cent of clergy point out that their parents and grandparents talked about political processes in their presence. This question shows no significant changes from denomination to denomination (42.9 to 63.8 per cent). This was also an open question, where clergy could share their comments (53.4 per cent used this opportunity) about the opinions their parents had towards politics and the existing regime. Their answers can be grouped into three categories: a negative attitude, which primarily is concerned with the Soviet regime (45 comments); a positive attitude ( 3 comments), and a neutral attitude ( 16 comments). The period prior to regaining independence comes out as a separate period (6 comments). Theoretically these factors of political identification should influence the political behaviour of clergy, and therefore it was important to analyse additional conventional and unconventional forms of political participation that they have used in the recent years. The results show that one of the most popular forms of political participation for clergy is communication with public servants - 65.6 per cent of clergy admit that they have contacted a public servant in the past 5 years. Partially this may be explained by the fact that Latvia is a small country and many clergy members are active members of the society (especially at the local level), which gives them ample opportunity to communicate with state officials. Data show that Adventist and Catholic clergy demonstrate the lowest levels of political participation in this respect (14.3 per cent on average).

One of the primary aspects of political participation is participation in political parties. The results show that 2.3 per cent of the surveyed clergy are currently members of a political party (Lutheran clergy are 5.2 per cent), though 
19.4 per cent of Baptist clergy, 9.5 per cent of Adventist clergy and 3.5 per cent of Catholic clergy at one point or another have been members of a political party. 42.7 per cent of those surveyed admit that they are not sure whether they would ever want to join the ranks of any political party, and only 37.4 per cent of clergy agree that they never have been, and never will be members of any political party.

Political culture is an important indicator of a successful democratic environment, but present research on political culture in Latvia characterise it as weak, bordering on subject and participatory political culture types. One of the key factors for this is the low level of trust in political institutions. Precisely for this reason trust levels in Saeima, Cabinet of Ministers, the President and political parties was measured and compared in correlation in this study. The study showed that there is a strong correlation in trust levels - those who distrust any institution, distrust other as well. E.g., if they distrust Saeima, they distrust the Cabinet of Ministers ( $\mathrm{r}=0.840)$, or political parties ( $\mathrm{r}=0.999)$; however, even though the majority of clergy distrust political institutions, they still trust in their fellow men $(\mathrm{r}=0.658)$.

The second section of the questionnaire helped to determine the political participation of clergy within the framework of their congregation. The study tried to reveal the sociopolitical forms of participation in their congregations, in which they have participated in the past 5 years. The results show that 55.7 per cent of clergy admit to having encouraged their congregation members in informal conversations to participate in elections; 33.6 per cent admit that they have done so during services, though only 6.1 per cent admit to having convinced some congregation members for whom to vote. Second, 54.2 per cent say they have prayed publically for a political issue and 31.3 per cent admit that they have publically prayed for a certain politician. 
The following two questions in this section tried to determine, whether prior to the elections of the 10th Saeima they had displayed any political party merchandise or symbols in their church. An affirmative answer was received from all denominations (except for Methodists), thus revealing that the merchandise of political parties was available in 7.1 per cent of churches in Latvia. Percentagewise the majority of cases were reported from Catholic (15.4 per cent), Baptist (12.9 per cent) and Adventist clergy (5.0 per cent). 10.8 per cent of clergy also admitted that a famous politician had spoken at their church within the past year.

The third section addressed questions, which helped find answers to social theology of clergy, including questions on Civic Religion, Christian Orthodoxy and Civil Gospel. Additional questions were included to determine their opinion on questions, which appear in the agenda of Church and State relations in Latvia.

In the first group clergy members had to evaluate certain statements with five answers (ranging from totally agree to totally disagree), and they were linked to Civic Religion, and determined how they see Church and State relations, as well as the role of the Church in politics. The first statement in this category dealt with whether clergy perceive the participation of other clergy members in politics as a positive phenomenon. The majority of them pointed that they totally disagreed (32.1 per cent) or rather disagreed (31.3 per cent). Of all the respondents only 4.6 per cent believe that this is a positive phenomenon and 17.6 per cent thing it is rather positive. The second statement - to involve or not to involve in politics should be the decision of each individual, irrespectively of their occupation. 35.1 per cent of clergy said they rather agreed, whereas 21.4 per cent totally agreed with this statement. Both, Methodist and Baptist clergy were more open towards personal beliefs, whereas Catholic and Adventist clergy either rather disagreed (30.8 and 31.8 per cent), or totally disagreed (17.2 and 9.1 per cent) with this statement. The next 
statement said - the Christian church sufficiently influences political processes in Latvia. This was one of the rare occasions when clergy had similar opinions, as only 1.5 per cent believe that the Church sufficiently influences political processes in Latvia (only Catholic (7.7 per cent) and Lutheran clergy), and 6.9 per cent believe that almost sufficiently. However the majority of respondents indicated that they rather disagree (48.1 per cent) or totally disagree with this statement (26.0 per cent). This answer shows that the clergy of institutional churches, which are numerically larger also feel more their sphere of influence and perceive it positively.

The last statement of this section dealt with the issue on whether the State appreciates the role the Church plays in the society. 27.5 per cent of clergy said they totally disagreed and 40.5 per cent said they rather disagreed with this statement. Only 18.3 per cent partially agreed and 0.8 per cent totally agreed with this statement. In order to better understand how clergy see the role of the Church in the State, they were asked to share their views in an open question. 48.1 per cent of clergy shared their opinion, and their answers can be grouped into several categories - evaluation of the situation, role of the Church in the spiritual field, and role of the Church in politics. Only two of all who commented shared a critically positive opinion on this question, admitting that there is a dialogue between the Church and the State in which the State takes into consideration the Church, or at least listens to its opinion. However, the majority of clergy said that they see the role of the Church in today's society as weak. In order to explain the Churches' role they used words like "very weak", "minimal", "insufficient”, "powerless", "barely visible”, "neutral”, "inadequately small", "secondary", "very average" and "should be more prominent". Many said that the Church's role was "being a representative signboard". At the same time many of them said that the problem had little to do with politicians and the State, and that churches themselves are to be blamed for this situation. Others who commented also indicated that the Church 
primarily can or should influence spiritual processes in the country, rather than political. Several clergy members said that "the Church is the salt of the earth", or used the term "conscience of the State", and indicated that the primary function of the Church was to involve in the spiritual field - "to develop human spirituality", "serve the society" and "help overcome hardships".

Even though the majority or clergy believe that the role of churches is too small in the country, none of those who commented said that politics could be one of the ways how to improve the situation. Quite the contrary - those who expressed their opinion clearly indicated that churches should associate themselves as little as possible with political processes in the society.

The next section in the third part dealt with issues associated with social theology and Christian Orthodoxy. Questions on Christian Orthodoxy primarily were directed towards gaining an understanding on what theological differences there are among the various denominations. In the recent years studies have found that there is an increasing socio-political activity from clergy who are fundamental in their beliefs, and believe, e.g., that the Bible is an infallible and a literal Word of God. In the case of Latvia, the majority of Protestant clergy totally agreed with this statement - Baptists $87.1 \%$, Lutherans 75.9\% and Methodists 57.1\%. However, also Catholic clergy shared a similar belief (53.8\%) and scored higher than Adventist clergy (40.9\%).

The next question concentrated on determining differences between institutional and non-institutional churches, therefore they had to say, whether they agreed that Church traditions and rituals are just as important as the Bible. Neither Methodist, nor Adventist or Baptist clergy agreed with this view, and only 3.4 per cent of Lutheran clergy agreed with it. However, the majority of Catholic clergy or 69.2 per cent did agree with this view. The theoretical thesis of clergy political behaviour was confirmed, because even though Catholic clergy demonstrate lower levels of average levels of their individual sociopolitical behaviour, have a positive outlook towards church and state relations. 
The last question of this section dealt with the question, whether salvation is possible through works. Same as in the first question, this too showed the differences between Protestants and Catholics. For example, 100 per cent of Adventist, 90.3 per cent of Baptist and 79.4 per cent of Lutheran clergy believe that salvation is not possible through works. And only 23.1 per cent of Catholic clergy shared the same opinion, whereas Methodist clergy were split in their opinions (57.1 per cent totally disagree, 28.6 per cent rather disagree and 14.3 per cent totally agree). This was also the first question where clergy of one denomination (Adventists) showed a 100 per cent consensus. Correlation data show that questions on the authority of the Bible and Church traditions correlate moderately $(\mathrm{r}=0.208)$, same as salvation is possible through works $(r=0.212)$ and authority of the Bible and Church traditions $(r=0.661)$.

The next group of questions included statements on the doctrines of the Christian faith. On the question, whether Adam and Eve were historic persons, Adventist (72.7 per cent), Methodist (71.4 per cent), Baptist (71.0 per cent) and Lutheran (67.0 per cent) clergy were most conservative, whereas only 46.2 per cent of Catholic clergy agreed with this statement. But they do share very similar views on the question, whether Jesus is the only Saviour, since 100 per cent of Catholic, Methodist and Baptist clergy totally agree with this, and Lutheran and Adventist clergy are close by with 98.3 and 95.5 per cent.

As far as the last three questions on doctrine are concerned, whether Jesus was born to a virgin, whether Satan exists and whether Jesus will come again, it is possible to note similarities, as 100 per cent of Catholic and Baptist clergy, 96.6 per cent of Lutheran, 90.9 per cent of Adventist and 85.7 per cent of Methodist clergy totally agree that Jesus was born to a virgin. Similarly, 100 per cent of Catholic, Baptist and Methodist clergy are convinced that Satan exists, and only 3.4 per cent of Lutheran and 8.4 per cent of Adventist clergy partially agree or partially disagree that Satan is a real evil that exists. However, clergy demonstrate agreement on the issue of eschatology, since 100 per cent of 
Catholic, Baptist, Adventist and Methodist clergy and 96.6 per cent of Lutheran clergy are convinced that Jesus will come again.

The third part of the questionnaire studied Civic Gospel or questions relating to the views of clergy on political processes in the country. When asked for their opinion on whether Christian values are currently at a threat in Latvia, the majority of clergy said they totally agreed (Catholics 92.3, Methodists 85.7, Baptists 51.6, Lutherans 44.8 and Adventists 45.5). 100 per cent of Catholic and 72.4 per cent of Lutheran clergy also agree that the State should take more care of the Christian heritage. Numerically smaller denominations, whose real estate properties do not include as many cultural and historic buildings were divided on this issue -32.3 of Baptist and 36.4 of Adventist clergy rather agree with this statement.

The next question asked, whether the free market is the only economic system that is compatible with Christian values, revealing a variety of opinions. Methodist clergy were the only ones of whom 57.1 per cent rather disagreed with this view. The majority of clergy within a range of 20 to 30 per cent indicated that they cannot answer this question. This clearly shows that this is one of the questions where they do not have a formed opinion. The principle that the ideas of liberal economy strongly correlate with democratic development through Christian teaching is still not taught in Latvian schools, nor was it ever mentioned during the Soviet era.

The clergy also demonstrate varying opinions, when asked if there is one Christian view on all political issues, because 63.6 per cent of Adventist, 48.3 of Lutheran, 28.6 of Methodist and 25.8 per cent of Baptist clergy totally disagree with this view. Even though many clergy members admitted that they cannot answer this question, Catholic clergy rather disagree (30.8 per cent) or totally disagree (23.1 per cent). Thus we can conclude that there are very few clergy members in Latvia with extreme or radical views, since the majority of them admit that even though Christian beliefs are important, they do not support 
a fanatic of radical policy. This was supported also by their answers on the last question of this category - whether it is difficult for politicians who are liberals to be Christians. In their answers they were not categorical, and even though 53.8 per cent of Catholic clergy totally agree, the majority of clergy rather disagree with this statement.

The last category of questions dealt with Church agenda issues, which appear in the media in Latvia (see Chapter 3.1). 85.7 per cent of Methodist, 69.2 per cent of Catholic, 56.9 per cent of Lutheran, 35.5 per cent of Baptist and only 4.5 per cent of Adventist clergy support the idea of Religious Studies being a compulsory subject in elementary schools. This was the question that split clergy views most of all on the issues listed in this category.

Greater unanimity among clergy can be observed on issues like the ban of abortion, where 92.3 per cent of Catholic clergy totally agree with this statement, followed by 67.7 of Baptist clergy. Adventist clergy are split on this issue, as 13.6 per cent totally disagree. On the last two questions the opinions are somewhat similar, as 92.3 of Catholic, 87.1 of Baptist, 81.8 of Lutheran, 63.6 of Adventist and 57.1 per cent of Methodist clergy believe that homosexual partners should not be granted the same rights as heterosexual partners, and 100.0 of Catholic, 71.0 of Baptist, 70.7 of Lutheran, 51.1 of Methodist un 27.3 per cent of Adventist clergy believe that euthanasia is a sin.

To understand answers to these questions they should be viewed in correlating categories. Several features can be observed. First, the most important correlation ( $\mathrm{r}=0.988)$ exists between clergy who believe that religious studies should be taught in schools and that homosexual partners should not be granted the same rights as heterosexual partners. Second, between those who believe that the Bible is an infallible and a literal Word of God, and homosexual partners should not be granted the same rights as heterosexual partners $(\mathrm{r}=0.408)$, and that religious studies should be taught in schools $(\mathrm{r}=0.398)$. It is 
unclear, why clergy have varying opinions on the ban of abortions $(r=-0.043)$ and ban of euthanasia $(r=-0.023)$.

The theoretical part of this thesis already explained that the political behaviour and socio-political activities of clergy are sometimes stimulated by their personality, which manifests through their charisma. Clergy members were asked to evaluate their own charisma from 1 to 10 ( 1 being none at all and 10 to a great extent). Even though these measures are subjective evaluations, they show that clergy evaluate themselves on average with 5.9 (std. deviation 1.82). Methodist clergy consider themselves to be most charismatic (6.1 on average), followed by Lutheran (6.0), Baptist (5.9), Catholic (5.8) and Adventist clergy (5.5).

After this they were asked, whether they have formed close ties with politicians or other people who are closely associated with politicians. Slightly more than half (53.4 per cent) responded that they do not have close ties with politicians, and 33.6 per cent said they had. The majority of Lutheran (44.8 per cent), Baptist (35.5 per cent) and Catholic clergy (30.8 per cent) have such contacts, whereas Methodist (14.3 per cent) and Adventist clergy (9.1 per cent) have least of all. The last question of the questionnaire asked whether any politicians or people close to them have ever asked to support them publically, e.g., asking people to vote for them in the elections etc. 39.7 per cent of clergy confirm that such requests have been expressed. The majority of these requests have been received by Catholic (46.2 per cent), Lutheran (44.8 per cent), Adventist (36.4 per cent), and Baptist clergy (35.5 per cent), and least of all by Methodist clergy (14.3 per cent). A characteristic nuance in this answer is that the number of requests by politicians is proportional to the size of each denomination, thus the hypothesis that church and congregation size is proportional to the political behaviour of clergy in a sense is confirmed.

If we look at correlation data where clergy charisma is compared to their age, number of attendants, annual income of the congregation as well as 
their ties to politicians, and requests to support them publically, we see that a notable correlation shows only with clergy who have close ties with politicians, and the request to support them $(r=0.218)$. Surprisingly charisma and close ties with politicians shows inverse correlation $(\mathrm{r}=-0.232)$, thus in the case of Latvia this hypothesis is not confirmed. Additionally, charisma does not correlate with age, and only minimally correlates with the number of people who attend services $(\mathrm{r}=0.013)$, and annual income of the congregation $(\mathrm{r}=0.084)$.

$* * *$

Several conclusions can be drawn from the empirical study:

First, clergy can be characterised as a comparatively politically active part of the society in Latvia. This is shown most clearly in the data about their political behaviour in elections. The level of participation in the last three Saeima elections has been above 80 per cent, which exceeds the average levels of participation by 20 per cent. Similar results relate to the elections of the European Parliament, Local elections and referendums (Catholic and Adventist clergy are most passive). They are also active participants of civil society since almost half of them (47.9 per cent) are involved at least in one NGO (Catholic and Methodist clergy are most passive). The average data on their political behaviour show that Lutheran (31.0 per cent) and Baptist clergy (30.2 per cent) are most active, followed by Methodist (27.3 per cent), Catholic (28.5 per cent) and Adventist clergy (18.1 per cent).

Second, clergy are politically active within their congregations. Average data on socio-political activity shows that Lutheran (31.0 per cent) and Baptist clergy (30.2 per cent) are most active, followed by Methodist (27.3 per cent), Catholic (28.5 per cent) and Adventist clergy (18.1 per cent). The most popular forms of socio-political activity during services are encouragements to participate in elections (58.3 per cent), public prayers for political issues (56.5 per cent), sermons on social and political themes (51.5 per cent) as well as 
encouragements to participate in elections during sermons (41.2 per cent). The lowest levels of activity can be observed on issues like displaying political party merchandise in churches ( 7.4 per cent), convincing church members to vote for specific political parties (5.8 per cent), sharing their personal political views during services (3.9 per cent) as well as requesting to vote for a particular political candidate (1.1 per cent).

Third, as far as determining factors of the political behaviour of clergy are concerned, we see that slightly more than half of all clergy or 55.7 per cent heard their parents and grandparents talk about politics, and actively commented on political issues in the State. Based on their answers about the attitude that was shared, we see that it was highly negative and disloyal to the Soviet regime, demonstrating resistance at least in the ideological sphere by refusing to join pioneers, Komsomol, at the same time continuing to pray for their country and leaders.

When we analyse issues of social theology as determining factors of political behaviour, we see that Catholic clergy are most categorical (77.9 per cent totally agree or disagree) on many issues of Civic Gospel and Civic Religion, which may be explained by the fact that the Catholic Church is the only one of the studied denominations that has a developed teaching on social issues. The next level is demonstrated by Lutheran clergy (65.5 per cent), followed by Methodist (64.3 per cent), Baptist (62.1 per cent) and Adventist clergy (47.7 per cent).

Fourth, as far as stimulating factors of political behaviour of clergy are concerned, we see that denomination has little effect on the model of their political behaviour. The empirical study clearly shows that the lowest levels of political behaviour were demonstrated by Adventist and Catholic clergy, which in almost all forms of political participation, including elections, are most passive. The socio-political behaviour of Adventist clergy is most noticeable, because they were also most sceptic towards the activities of Latvian First 
Party as only 14.3 per cent of Adventist clergy have voted for them. They also demonstrated the lowest levels of trust in political institutions as well.

However, clergy age reveals much more about their political behaviour. The study showed that clergy in the age group from 31 to 45 systematically demonstrated higher levels of political activity than clergy from other age groups. This allows us at least partially also to explain the low levels of political participation among Adventist clergy, since of the total number of clergy who participated in the study, Adventist clergy are proportionally the oldest, since more than half of them are more than 46 years old. 


\section{CONCLUSIONS}

The aim of this thesis was to analyse and compare the political behaviour of clergy of traditional denominations in Latvia and identify the reasons for their activity. This was achieved by fulfilling the following tasks and drawing the following conclusions:

- Institutional secularisation and separation of Church from political and social processes enhances the political activity of many clergy members, because their goal is to upkeep the institutional influence of the Church, as well as moral values in the society.

- Analysis of theoretical literature on the relationship of politics and religion shows that the political behaviour of clergy is determined by: individual factors (personal experience acquired through family and the Church) and theological beliefs (social theology).

- The description of Church and State relations in Latvia since the foundation of the State showed that traditional denominations are recognised, and they have all signed contracts with the State, defining their sphere of activity and functions in the society.

- The characterisation of the historic political behaviour of clergy in Latvia showed that during the pre-war period more than half of all elected clergy MPs in the Saeima were Lutheran (7) and Baptist (2) clergy members. The socio-political activity of Catholic (4) and Orthodox (1) clergy was also notable. Clergy were important personalities and part of the intelligentsia of that time, which mustered large masses of people around themselves. Adventist, Methodist and Old-believer clergy have kept away from politics since the 20s, allowing for their laymen to involve in political activities. No more than three clergy members have been elected in the 5th through 11th Saeima, and since the restoration of independence only protestant clergy have been elected (Lutherans (4) and Baptists (2)). Primarily this factor has 
been affected by secularisation trends in the society and the introduction of the 5 per cent electoral threshold.

The following tasks were completed in order to test the hypothesis listed in the Introduction:

- Analysis of periodicals published in the last 10 years helped determine that the political behaviour of clergy is stimulated from the outside (by politicians/political parties) as well as by their personal initiative. Four distinct themes dominate the discussions between clergy members and state representatives: Christian values (an undefined number of issues); family values (juxtaposed to sexual minority issues); education issues (primarily religious education in public schools); and integration issues (national aspects, language and integration issues), revealing that there are various opinions among the clergy of Christian denominations on the last issue.

- Empirical study (quantitative method - surveying) helped to determine the political behaviour and socio-political activity of clergy.

Based on the results of the empirical study, the first hypothesis was confirmed only partially:

H1 Socio-political activities of protestant and evangelical clergy are higher than those of Catholic, Orthodox and Old Believer clergy, which is affected by the freedom of ritual in their churches.

Since Orthodox and Old-believer clergy had to be excluded from the quantitative study, and only 7.8 per cent of Catholic clergy participated in the study, specific conclusions based on the quantitative study cannot be drawn. At the same time, the responses of Catholic clergy that did participate in the survey show that the hypothetical assumption is at least partially true, since Catholic clergy in comparison to clergy of other denominations showed much lower levels of political behaviour and political participation, especially if compared to Lutheran and Baptist clergy. This corresponds to what was concluded elsewhere in this thesis that the clergy of highly institutionalised denominations 
are usually less active in politics, because their Churches are able to reach their goals more effectively with institutional methods.

The second hypothesis was not confirmed:

H2 The political behaviour of clergy is primarily determined by their denomination, rather than their age, or location of the Church.

According to the interdenominational comparison of clergy one of the most prominent features was that all clergy members (except for Adventist clergy) shared very similar models of political behaviour - both, general as well as those that manifest within their congregations. Clergy members systematically demonstrate higher levels of political participation than observed on average in the society in Latvia. Therefore it was very important to identify factors that determine the political behaviour of clergy. The study shows that the most important factor is age, because clergy in the age group from 31 to 46 are politically most active. The location of the Church marked a slight difference on the trends of political behaviour, since clergy from towns are slightly more active than those from Rīga and country parishes.

\section{The third hypothesis was confirmed:}

H3 The political behaviour of clergy is stimulated by their personal theological views on social issues - affective and evaluative beliefs on Church and State relations.

Even though distinctly conservative trends dominate the theological views of clergy in Latvia, and it applies to all clergy members (irrespectively of their denomination), similarly to studies carried out in other countries, the clergy in Latvia who believe that the Bible is an infallible and a literal Word of God (primarily Baptists and Lutherans) also demonstrate higher levels of participation in socio-political forms. Respectively Adventist clergy, who least agreed with this statement also showed the lowest levels of political participation, and therefore we may conclude that this hypothesis was confirmed. The same applies to Catholic clergy who even though demonstrate average levels of political participation, are positive in their evaluation of 
Church and State relations. The clergy of institutionalised churches are comparatively inactive, whereas their Churches in their political goals and activities are effective.

\section{The fourth hypothesis was confirmed:}

H4 The political behaviour of clergy is encouraged from the outside, i.e., political party members desire to decrease the alienation that is taking place in the society, and the Churches in return desire to spread the Christian message and promote spiritual values in the secular society.

The study as well as interviews with the heads of churches reveal that politicians tend to express requests to clergy members to support them during electoral campaigns. Clergy from all denominations testified to this, with 39.4 per cent of all respondents admitting to this. The activity differs from denomination to denomination, e.g., a majority of such requests has been expressed to Catholic (46.2\%), Lutheran (44.8\%), Adventist (36.4\%) and Baptist clergy (35.5\%), whereas least of all to Methodist clergy (14.3\%). What is surprising is that these requests are proportional to the size of each of the denominations. This is an indication that the assumption that the size of the Church correlates with the political activity of clergy in a sense is confirmed.

It would be advisable to study the political behaviour of clergy of new religious movements in the future, and to receive the approval of the Catholic Church and LOC for studies like this. This study confirmed the information that appears in Western scientific literature at least as partially true that these churches tend to be closed and veiled in secrecy (this applies to the Orthodox and Old-believers in particular). Researchers who are members of these churches might have an opportunity to carry out this research, since they would face less suspicion and more understanding from the leaders of these Churches.

In the end, I would like to point to one of major problem in the field of this thesis in Latvia - neither the media, the society, nor even various so called "experts of the field" distinguish a difference between the terms state and church, and politics and religion, as a result of which many misunderstandings 
arise in normative terms and praxis whenever paragraph 99 of the Constitution is mentioned. Whenever we talk about the Church and State we are talking about two institutions and their spheres of influence. In this respect they are definitely separated in Latvia, and it manifests in two ways: 1) Legally - the Church is separated from the State, which means that the government of Latvia does not appoint church clergy nor in any other way affects the internal activities within churches. Similarly, churches in Latvia do not dictate political processes - they do not appoint political leaders, and in order to become a public servant one does not need the support of the Church. 2) Practically - the State as well as the Church respect each other's legal framework and even though they have a positive collaboration, they look for compromises through consensual negotiations whenever conflict situations arise.

At the same time, it is much more difficult to separate the sphere of politics and religion. First, many citizens who are active in politics can also be members of a certain church or a religious group. This dual connection causes problems, because it is nigh impossible to separate when somebody is speaking as a politician, and when as a Christian.

Second, as mentioned before in this thesis, clergy members are also citizens of their country, and thus they share the same civil rights and obligations as other citizens of Latvia. The fact that they are employed by the Church should not mean that they are excluded from fulfilling their obligations as a citizen. And as the study clearly showed, many clergy members are politically more active than the rest of the society, and they demonstrate high levels of political participation, whereas others are passive observers of political processes who neither participate in them, nor are interested in them, thus becoming typical "apolitical" citizens. This raises an additional question of how well can one person combine two offices at the same time; however, this is an issue that remains to be settled by each individual Church. 
Third, similarly as other groups in civil society - the Churches as institutions often share their opinion and support their interests, which in accordance with democratic values no one can prohibit them from doing. If we look at this issue from a strictly democratic practice point of view this is not only favourable, but highly necessary. Therefore it is inadequate to attribute paragraph 99 of the Constitution to the field of religion and politics.

As long as churches in Latvia continue to retain high levels of trust, there will always be politicians and political parties, who will try to acquire the support from Christians and in doing so they will position themselves as trustworthy partners that the Churches can collaborate with. And it is also safe to believe that there will be people in these parties who will do this to pursue their mercantile goals, and there will be others, possibly laymen of these same churches, who will act in accordance with their conscience, and will truly strive to represent the interests of the Church. It is also quite clear that clergy members will continue to uphold a dialogue with the State, including political parties and their members. The only question that remains is whether the clergy who have been doing this for the past 10 years will continue this cooperation in the future. Even though the study confirmed that the majority of clergy have a strictly negative attitude towards some of their colleagues 'flirting' with political powers, it is questionable whether Churches will want to change this status quo. And it is highly doubtful that it will ever be possible to draw a strict line of separation in this relationship, especially as secularisation takes its stronghold. The more the Church will be pushed outside of the political and social sphere, the more their clergy as full-fledged subjects (institutional and individual) and representatives of civil society, will continue to stand for their interests, which according to the Constitution and generally accepted democratic principles, they may and should continue to implement. 


\section{BIBLIOGRAPHY}

1. Balodis, Ringolds. Valsts un baznīca. Rīga: Nordik, 2002

2. Crawford, Sue E. S., Olson Laura R. "Clergy as Political Actors in Urban Contexts" in Christian Clergy in American Politics, ed. Sue E. S. Crawford, Laura R. Olson, Baltimore and London: The John Hopkins University Press, 2001

3. Gill, Anthony and Arang Heshavarzian, "State Building and Religious Resources: An Institutional Theory of Church-State Relations in Iran and Mexico." Politics \& Society, SAGE Publications, Vol. 27, No 3 (September 1999): 431-465

4. Gill, Anthony. "The Economics of Evangelisation." In: Evangelisation and Freedom in Latin America. Edited by Paul Sigmund. Maryknoll New York: Orbis Books, 1999

5. Guth, James et al. The Bully Pulpit: The Politics of Protestant Clergy. University Press of Kansas, 1997

6. Guth, James et al., "The Political Activity of Evangelical Clergy in the Election of 2000: A Case Study of Five Denominations." Journal for the Scientific Study of Religion. Issue 42, Vol. 4 (2003):501-514

7. Hoppenbrouwers, Frans. "Romancing Freedom: Church and Society in the Baltic States since the End of Communism." Religion, State \& Society Vol. 27, No. 2 (Routledge, 1999):161-173

8. Iannaccone, Laurence. "Religious Practice: A Human Capital Approach." Journal for the Scientific Study of Religion Vol. 29, No 3 (1990):297314

9. Jelen, Ted. G., "Notes for a Theory of Clergy as Political Leaders." In Christian Clergy in American Politics, ed. Sue E. S. Crawford, Laura R. Olson, Baltimore and London: The John Hopkins University Press, 2001

10. Jesajas61.lv „Kandidāti. Pjotrs Aleksejevs” Portāls Jesajas61.lv http://www.jesajas61.lv/lv/kandidati/pjotrs_aleksejevs

11. Kalniņšs, Jānis. Svētais Rīgas Jānis. Rīga: Jumava 2001

12. Malahovskis, Vladislavs. „Katoḷu Baznīcas politiskās aktivitātes neatkarīgajā Latvijā." Via Latgalica, Rēzeknes Augstskolas Reǵionālistikas institūts (2009 II):78-94

13. Rancāne, Anna. Ināra Egle, Dita Arāja. „Politiķu slavināšanai izmanto dievnamu." 23.12.2004. Diena. http://www.diena.lv/arhivs/politikuslavinasanai-izmanto-dievnamu-12260308 
14. Raita, Santa. „Baznīcu izmanto politiskajās cīņās.” 20.04.2004. Neatkarīgā Rìta Avīze. http://news.lv/NeatkaRīga_Rita_Avize_Latvijai/2004/04/20/ Baznicu-izmanto-politiskajas-cinas

15. Rémond, René. Religion and Society in Modern Europe. Oxford: Blackwell, 1999

16. Robinson, B. A. "How Many People Go Regularly To Weekly Religious Services?" November, 2001. Ontario Consultants on Religious Tolerance, www.religioustolerance.org/rel_rate.htm

17. Smidt, Corwin. "Clergy in American Politics: An Introduction." Journal for the Scientific Study of Religion Issue 42, Vol. 4 (2003):495-499

18.Zvirgzdiňš, Indulis. „1905. gads Lazdonas draudzē.” Raksts no starptautiskas konferences „Informācija, revolūcija, reakcija: 19052005” (2005. gada 23.-25. novembris, Rīga) materiālu krājuma, http://academia.Indb.lv/xmlui/bitstream/handle/1/651/indulis_zvirgzdins _1905_gads_lazdonas_draudze.pdf?sequence $=1$ 


\section{SCIENTIFIC ARTICLE ON PROMOTIONAL THEME}

1. Gurbo, Simona. "Dynamics of Church and State Relations in Latvia after the Collapse of the Soviet Union", Punctum Temporis, 1/IV (2010):25-30

2. Gurbo, Simona. „Garīdznieku sociālpolitiskā darbība protestantu draudzēs Latvijā", Zinātniskie raksti. Sociālo zinātnu nozares pētniecisko darbu publikācijas, RSU (2009):65-76

3. Gurbo, Simona. „Protestantu garīdznieku attieksme pret valsts un baznīcas politiskajām attiecībām Latvijā", Zinātniskie raksti. Sociālo zinātņu nozares pētniecisko darbu publikācijas, RSU (2009):119-130

\section{PUBLISHED THESIS}

1. Gurbo, Simona, Ilga Kreituse (June 2012). Politics and the Pulpit: Political Behaviour of Clergy in Latvia. Unpublished conference paper presented at 2nd Annual General Conference of the European Political Science Association, Berlin (Germany)

2. Gurbo, Simona (September 2010). The Socio-Political Behaviour of Protestant Clergy in Latvia. Unpublished conference paper presented at 3rd ECPR Graduate Conference, Dublin City University, Dublin (Ireland)

3. Gurbo, Simona, „Politiskā ag̣itācija Latvijas baznīcās pirms 10. Saeimas vēlēšanām" (Tēzes), Rīga: RSU (2011):380

\section{CONFERENCES}

1. Gurbo, Simona, Ilga Kreituse (June 2012). Politics and the Pulpit: Political Behaviour of Clergy in Latvia. Conference paper presented at 2nd Annual General Conference of the European Political Science Association, Berlin (Germany)

2. Gurbo, Simona (September 2011). Church and State Relations in Latvia: Religion and Religious Issues as a Political Weapon in Electoral Campaigns. Conference paper presented at 10th Conference of the European Sociological Association, Geneva (Switzerland)

3. Gurbo, Simona (September 2010). The Socio-Political Behaviour of Protestant Clergy in Latvia. Conference paper presented at 3rd ECPR Graduate Conference, Dublin City University, Dublin (Ireland)

4. Gurbo, Simona, „Politiskā ag̣itācija Latvijas baznīcās pirms 10. Saeimas vēlēšanām”, Rīga: RSU (2011):380 